University of Michigan Law School

University of Michigan Law School Scholarship Repository

\title{
A Dissent from the Miranda Dissents: Some Comments on the 'New' Fifth Amendment and the Old 'Voluntariness' Test
}

\author{
Yale Kamisar \\ University of Michigan, ykamisar@umich.edu
}

Available at: https://repository.law.umich.edu/book_chapters/18

Follow this and additional works at: https://repository.law.umich.edu/book_chapters

Part of the Constitutional Law Commons, Criminal Procedure Commons, Law Enforcement and Corrections Commons, Legal History Commons, and the Supreme Court of the United States Commons

\section{Publication Information \& Recommended Citation}

Kamisar, Yale. "A Dissent from the Miranda Dissents: Some Comments on the 'New' Fifth Amendment and the Old 'Voluntariness' Test." In Police Practices and the Law: Essays from the Michigan Law Review, 281-326. Ann Arbor: Univ. of Michigan Press, 1982.

This Book Chapter is brought to you for free and open access by the Faculty Scholarship at University of Michigan Law School Scholarship Repository. It has been accepted for inclusion in Book Chapters by an authorized administrator of University of Michigan Law School Scholarship Repository. For more information, please contact mlaw.repository@umich.edu. 


\title{
A DISSENT FROM THE MIRANDA DISSENTS: SOME COMMENTS ON THE "NEW" FIFTH AMENDMENT AND THE OLD "VOLUNTARINESS" TEST
}

\author{
Yale Kamisar*
}

The world and the books are so accustomed to use, and over-use, the word "new" in connection with our country, that we early get and permanently retain the impression that there is nothing old about it.-Mark Twain (1883) ${ }^{1}$

$[F]$ or the very reason that those in authority have no right to require a disclosure, those without authority feel justified in seeking to worm it out by threats, by fraud, by holding out false hopes, by putting forward false pretenses ... Unwilling to allow a magistrate to institute, as a matter of course, a formal examination, and place the result on record, we leave the same information to be fished for by the sheriff who makes the arrest, by the jailer, by the fellowprisoner turned informer or by the detective in disguise, and only require the witness who proves it to add perhaps perjury to fraud in swearing that no undue means were used to elicit the confession.-Simeon E. Baldwin (1883) ${ }^{2}$

$I^{\prime}$ F the several conferences and workshops (and many lunch conversations) on police interrogation and confessions in which I have participated this past summer ${ }^{3}$ are any indication, Miranda $v$. Arizona $a^{4}$ has evoked much anger and spread much sorrow among judges, lawyers and professors. In the months and years ahead, such reaction is likely to be translated into microscopic analyses and relentless, probing criticism of the majority opinion. During this

- Professor of Law, University of Michigan.

The author is indebted to Steven Brodsky, a second-year student at the University of Michigan Law School, for his valuable research assistance.

1. Mark Twain, Life on THE Mississippi ch. I (1883).

2. Simeon E. Baldwin, Paper Read at Sixth Annual Meeting of the American Bar Association, printed in 6 A.B.A. REP. 225, 232 (1883).

3. For example, on the basis of four lively workshop sessions, lasting three full hours, with the Chief Justices of the States at the Eighteenth Annual Meeting of the Conference of Chief Justices, August 5, 1966, I would have to say they were overwhelmingly opposed to the recent confession rulings.

4. 384 U.S. 436 (1966) (Warren, C.J.). Actually, "the Miranda opinion" is an opinion for four cases: Miranda, No. 759; Vignera $v$. New York, No. 760; Westover v. United States, No. 761; and California v. Stewart, No. 584. Justices Harlan, Stewart and White dissented in all four cases, joining in separate dissenting opinions written by Justices Harlan and White. Justice Clark, who would continue to follow the "totality of circumstances" rule but assign increased weight to whether the appropriate warnings were given, see 384 U.S. at 499,503,504, dissented in three of the four cases but concurred in the result in California $v$. Stewart "if the merits are to be reached," id. at 504. (He preferred to dismiss the writ of certiorari in Stewart for want of a final judgment.) 
period of agonizing appraisal and reappraisal, I think it important that various assumptions and assertions in the dissenting opinions do not escape attention.

I must agree with Justice Harlan that "the fine points of this [the Miranda majority's] scheme are far less clear than the Court admits," 5 but I mean to treat this in another article. I do not deny that some aspects of the majority opinion are questionable, for example its defining "custodial questioning" —which must be preceded by warning the suspect that "he has a right to remain silent, that any statement he does make may be used as evidence against him, and that he has a right to the presence of an attorney, either retained or appointed"7-to include stopping and questioning on the street. ${ }^{8}$ I take it, however, that one may sharply dis-

5. 384 U.S. at 505. A number of questions about the reach of Miranda are raised in Hall \& Kamisar, Modern Criminal Procedure 450 (2d ed. 1966).

6. See note 43 infra and accompanying text.

7. 384 U.S. at 444 . This appears in the self-styled summary of the Court's holding. The warnings (and the reasons for them) are discussed in considerable detail at pp. 467-79 of the majority opinion.

8. Thus, although, as Judge Breitel had pointed out on the eve of Miranda, the controversy had centered on what rights the suspect enjoyed and what rights he was entitled to after he was brought to the police station, Breitel, Criminal Law and Criminal Justice, 1966 UTAH L. Rev. 1, 8-9, the Court manifested its willingness to enter a thicket "largely ignored by commentators and dealt with ambiguously by most courts." Remington, The Law Relating to "On the Street" Detention, Questioning and Frisking of Suspected Persons and Police Arrest Privileges in General, in Police Power and Individual Freedom 11, 15 (Sowle ed. 1962).

The Court has had much experience with police station interrogation (if anything, too much), but so far as I know it has never had occasion to consider the admissibility of a statement produced by "on the street" or "on the spot" questioning. I am convinced that the persistent, resuurceful, skillful police interrogator is no bogyman, but he operates within the confines of the stationhouse, not on the streets or even in the squad car. The average patrolman is of a different breed. I am readily persuaded by what the Court has to say about the substantial pressures generated by the isolation, secrecy and unfamiliarity of the "interrogation room," but the Court has virtually nothing to say about the inherently compulsive and menacing nature of "on the street" questioning.

I agree that the privilege protects an individual from being compelled to incriminate himself even though the compulsion be "informal" and "subtle" and that the privilege "does not distinguish degrees of incrimination," 384 U.S. at 476-once a certain degree is reached. Distinguishing degrees, after all, is inherent in the process of defining "compel" within the meaning of the privilege. That the requisite degree will sometimes be reached in the course of "field interrogation" I have no doubt. But always? Necessarily? Typically? Of course any questioning by a police officer anywhere generates some pressures and anxieties-" "what on their face are merely words of request take on color from the officer's uniform, badge, gun and demeanor." Foote, The Fourth Amendment: Obstacle or Necessity in the Law of Arrest?, in Police Power and Individual Frefdom 29, 30 (Sowle ed. 1962). This is also true, however, of "general on-the-scene questioning" and of police visits at a suspect's home or place of business, situations where, the Court tells us, the requisite warnings need not (or, at least, need not always) be given, because "the compelling atmosphere inherent in the process of in-custody interrogation is not necessarily present." 384 U.S. at 478. 
sent from portions of the Miranda dissents without warmly endorsing every aspect of the majority opinion. I take it that here, as elsewhere, one may spot the bad without committing himself to, or knowing, the perfectly good. ${ }^{\circ}$

Dissenting Justice Harlan, joined by Justices White and Stewart, utters a couple of "hurrahs" for the old test-"a workable and effective means of dealing with confessions in a judicial manner"10 and "an elaborate, sophisticated and sensitive approach to admissibility of confessions."11 The aim of the majority, he protests, "is

Finally, if the police must issue the Miranda warnings to one detained "on the spot," they are more likely to resort to the more drastic alternative of taking him down to the stationhouse. A stop may well be an "arrest" for some purposes, but it does not stigmatize a man the way a formal "arrest" for a felony does.

On the other hand, this is surely one of those "damned if it did" (cover field interrogation) and "damned if it didn' $t$ " issues which sometimes confront the Court. As the Court must have been well aware, confining the Miranda rules to stationhouse proceedings--which would have sufficed to dispose of all the cases before itwould have put enormous pressure on the police to intensify and widen the less visible "on the street" detention and to slow down or make more circuitous the ride to headquarters. See Moder Code of Pre-Arraignment Procedure $\$$ 5.01, comment at 174 (Tent. Draft No. 1, 1966); Developments in the Law-Confessions, 79 Harv. L. Rev. 935, 945 (1966). By defining "custodial questioning" to cover "field" and "squad car" questioning, the Court was understandably reaching out (albeit most gingerly) to protect its flanks. For drama and glamor it is hard to beat the "interrogation room" confession, but the "more humdrum" common practice of stopping and questioning raises "far more basic" issues. See Packer, Who Can Police the Police?, The New York Review of Books, Sept. 8, 1966, pp. 10, 12.

True, the Court might have taken a "middle ground" on this troublesome cluster of issues and indicated that whether questioning of a person "deprived of his freedom in any significant way" is to be preceded by the requisite wamings should turn on the particular circumstances attending each incident, but to do so might have largely defeated its central purpose, which was to displace the unsatisfactory caseby-case approach in this field with a set of firm, specific, "automatic" guidelines. (The effects of its apparent exceptions for "general on-the-scene questioning" and police visits at a suspect's home remain to be seen.)

If the distinctions between "field interrogation" and "police station" questioning are without a difference for purposes of the requisite warnings, are they nevertheless significant for purposes of "waiver"? Is the "heavy burden" resting on the government to demonstrate that the suspect knowingly and intelligently waived his rights, 384 US. at 475 , appreciably lighter outside the relatively controlled environment of the stationhouse? Considering the greater confusion and higher incidence of "emergency situations" on the street, the substantially greater pressures usually operating in the police station, and the much more extensive means of corroborating evidence of warnings available there, much can be said for an affirmative answer. However, I do not find the answer in Miranda. Although I doubt that all those reading the Miranda opinion with a magnifying glass can be restrained from expounding in the meantime, this aspect of Miranda, above all others, will be brought into focus only by "new prodding of the new facts." Cf. Llewellyn, The Common Law Tradition 293 (1960).

9. Cf. Fuller, The Morality of Law 11-12 (1964).

10. 384 U.S. at 506 .

11. Id. at 508. Justice Clark, too, although he maintains that "the majority . . goes too far on too little, while my dissenting brethren do not go quite far enough," id. at 499 , retains considerable enthusiasm for the old approach:

Rather than employing the arbitrary Fifth Amendment rule which the Court 
toward 'voluntariness' in a utopian sense." 12 I submit that it is the dissenters who are the dreamers, not the majority. I venture to say that only one with an extravagant faith in the actual operation of the "totality of the circumstances" test could fail to see that the safeguards provided by the old test were largely "illusory." 13 Justice Harlan is distressed that the majority requires the police to show "voluntariness with a vengeance," 14 but I submit that, as his vote to uphold the confession in Davis $v$. North Carolina ${ }^{15}$ well illustrates, he would require the defendant to establish restraint, coercion and a breaking of the will "with a vengeance."

A victim of objectionable interrogation practices could only satisfy this test with some regularity in a utopian judicial world. This was not Davis' world. He could produce a specific notation on the arrest sheet to the effect that he was to be held incommunicado. He could also point to the undisputed fact that no one other than the police had seen him during the sixteen days of detention and interrogation that preceded his confessions. Moreover, on the basis of these confessions he was sentenced to death, which however painful otherwise, does not "hurt" one who is seeking to gain close appellate court scrutiny and reversal. Nevertheless, Davis lost in the state courts and, on habeas corpus, in the two lower federal courts. ${ }^{10}$ True, Davis is only one case, but most alleged victims of impermissible police interrogation enter the "swearing contest" with many fewer weapons.

The dissenters are startled at how the majority manages to leap over high historical and linguistic barriers to bring the privilege against self-incrimination into the interrogation room. "A trompe l'oeil,"17 proclaims Justice Harlan. "At odds with American and English legal history,"18 reports Justice White, joined by Justices

lays down I would follow the more pliable dictates of the Due Process Clauses of the Fifth and Fourteenth Amendments which we are accustomed to administering and which we know from our cases are effective instruments in protecting persons in police custody.

Id. at 503 .

\section{384 U.S. at 505 .}

13. A close student of the problem so characterized them a full twenty years ago, pointing to the almost insurmountable problems of proof confronting the alleged victim of improper interrogation practices. Dession, The New Federal Rules of Criminal Procedure, 55 Yale L.J. 694, 708 (1946).

14. 384 U.S. at 505 .

15. 384 U.S. 737 (1966) (on federal habeas corpus). Since, in another case handed down the same day, the Court declined to give the new rules retroactive effect, Johnson v. New Jersey, 384 U.S. 719 (1966), it applied the traditional confession rules to strike down the Davis confessions, Justices Clark and Harlan dissenting.

16. See the discussion at notes 164-82 infra.

17. 384 U.S. at 510 .

18. Id. at 531 . 
Harlan and Stewart. "Decisions like these," warns Justice White, "cannot rest alone on syllogism, metaphysics or some ill-defined notions of natural justice." 19

Miranda may leave something to be desired, but it deserves a better reception than this. True, it amounts to a substantial jump from Escobedo, ${ }^{20}$ which, in turn, marked a jump from Haynes. ${ }^{21}$ But Miranda is hardly a thunderbolt from the blue. It is unquestionably a sharp departure from the recent past, but if one travels back far enough_“"Oh, no!" many a reader will exclaim at this point. "Not another 'we but return to old principle' discourse."22 I sympathize with these readers.

Police-prosecution-minded critics of the courts can be exasperating; at least "they have often exasperated me. ${ }^{23}$ But champions of liberty and privacy can also be exasperating; at least they have even exasperated me. Every year I teach Adamson v. California, ${ }^{24}$ and though I never fail to pummel the majority opinion, I never fail to gag at Justice Murphy's dissent: "Much can be said pro and con as to the desirability of allowing comment on the failure of the accused to testify. But policy arguments are to no avail in the face of a clear constitutional command." 25 I joined in the general rejoicing when Gideon $v$. Wainwright ${ }^{28}$ was handed down, but I winced at Justice Black's assertion that "the Court in Betts $v$. Brady made an abrupt break with its own well-considered precedents" 27 and at his assurance that "in returning to these old precedents ... we but restore constitutional principles . . . ."28

I am well aware that for what I am about to say I, too, shall be accused of finding refuge in constitutional language whose specificity and immutability is largely illusory, of "returning" to a mythical past, or at least of being less impressed with historical facts which do not fit my theories than with those which do. I adhere

19. Id. at 531-32.

20. 378 U.S. 478 (1964).

21. 373 U.S. 503 (1963). But this was not nearly as long a jump as the many who were thunderstruck by Escobedo seemed to think. See Herman, The Supreme Court and Restrictions on Police Interrogation, 25 OHі STATE L.J. 449, 454-56 (1964).

22. See generally Israel, Gideon v. Wainwright: The "Art" of Overruling, in 1963 SUPREME Court Review 211, 234-42 (Kurland ed.).

23. See, e.g., Kamisar, On the Tactics of Police-Prosecution Oriented Critics of the Courts, 49 CORNELL L.Q. 436 passim (1964).

24. 332 U.S. 46 (1947), overruled in Malloy v. Hogan, 378 U.S. 1 (1964).

25. 332 U.S. at 125. Eighteen years later the Court did vindicate Justice Murphy's position, although it was not content to rest on a "plain reading" of the Constitution. Griffin v. California, 380 U.S. 609 (1965) (Douglas, J.).

26. 372 U.S. 335 (1963).

27. 1 d. at 344 .

28. Ibid. 
to the view that whether or not the Court's reading of the privilege against self-incrimination in Malloy $v$. Hogan"s "makes good sense, . . . it constitutes bad history-modern history, that is."30 I still maintain that although "the old Bram case might well have furnished a steppingstone to the standard advanced in Malloy, ... until Escobedo, at any rate, it only amounted to an early excursion from the prevailing multifactor approach."31 I claim only this:

(1) The linguistic and historical barriers, whatever they were, which lay in the path of Miranda's application of the privilege to "custodial questioning" were considerably less formidable than those surmounted when the privilege was applied to legislative investigations and civil proceedings. Yet long before Brown $v$. Mississippi, ${ }^{32}$ the Court's first fourteenth amendment due process confession case, it was settled, rightly or wrongly, that the privilege did apply to these latter proceedings. Given Counselman $v$. Hitchcock ${ }^{33}$ and McCarthy v. Arndstein,$^{34}$ Miranda appears to be an $a$ fortiori case;

29. 378 U.S. 1 (1964).

30. Kamisar, Equal Justice in the Gatehouses and Mansions of American Criminal Procedure, in Criminal Justice IN OUR TIME 47 (Howard ed. 1965).

31. Ibid. The reference is to Bram v. United States, 168 U.S. 532 (1897).

32. 297 U.S. 278 (1936).

33. 142 U.S. 547 (1892). The Court held that appellant need not answer questions asked in a grand jury investigation which would tend to incriminate him because the "protection of $\S 860$ [of the Revised Statutes] is not coextensive with the constitutional provision." Id. at 565. The statute protected appellant against direct use of his testimony in a criminal proceeding, but "could not, and would not, prevent the use of his testimony to search out other testimony to be used in evidence against him . . ." Id. at 564. Appellee argued that:

An investigation before a grand jury is in no sense "a criminal case." The inquiry is for the purpose of finding whether a crime has been committed and whether any one shall be accused of an offense. 'The inquiry is secret; there is no accuser, no parties, plaintiff or defendant. The whole proceeding is ex parte. Id. at 554. The Court retorted that:

It is impossible that the meaning of the constitutional provision can only be, that a person shall not be compelled to be a witness against himself in a criminal prosecution against himself. ... The object was to insure that a person should not be compelled, when acting as a witness in any investigation, to give testimony which might tend to show that he himself had committed a crime. The privilege is limited to criminal matters, but it is as broad as the mischief against which it seeks to guard.

Id. at 562.

In Emspak v. United States, 349 U.S. 190 (1955) and Quinn v. United States, 349 U.S. 155 (1955), the privilege against self-incrimination was successfully invoked by petitioners who refused to answer certain questions asked of them by the Committee on Un-American Activities of the House of Representatives. Members of the Court differed only as to whether petitioners had properly claimed the privilege for themselves; not even the dissenting justices / paused to consider whether a congressional investigation is "a criminal case."

34. 266 U.S. 34 (1924). Rejecting the government's broad contention that the privilege "does not apply in any civil proceeding," $i d$. at 40 , as well as its narrow contention that the privilege "does not relieve a bankrupt from the duty to give information which is sought for the purpose of discovering his estate," id. at 41, a unanimous Court observed, per Justice Brandeis: 
that is, unless one is prepared to rekindle the Twining-AdamsonMalloy debate.

(2) The prize for ingenuity goes not to the Supreme Court for finally applying the privilege to the police station but to those who managed to devise rationales for excluding it from the stationhouse all these years. Dwell for a moment on the reasoning that because police officers have no legal authority to compel statements of any kind, there is nothing to counteract, there is no legal obligation to which a privilege can apply, and hence the police can elicit statements from suspects who are likely to assume or be led to believe that there are legal (or extralegal) sanctions for contumacy. ${ }^{35}$ Is it unduly harsh to say, as those who do not use strong words lightly have, that such reasoning is "casuistic"36__"a quibble"?37

(3) Assuming a "first amendment privilege" which would relieve the fifth amendment of its burden in "belief probes," 38 most, if not all, that can be said for the privilege applies in spades to police interrogation. One would do well to start with what Professor John McNaughton, no warm friend of the privilege, concluded some six years ago after a painstaking analysis of the problem:

The significant purposes of the privilege remaining after the First Amendment albatross has been cut free ... are two: [1] The first is to remove the right to an answer in the hard cores of instances where compulsion might lead to inhumanity, the principal inhumanity being abusive tactics by a zealous questioner. [2] The second is to comply with the prevailing ethic that the individual is sovereign and that proper rules of battle between government and individual require that the individual not be bothered for less than good reason and not be conscripted by his opponents to defeat himself.

Both policies of the privilege which I accept, as well as most of those which I reject, apply with full force to insure that police in informal interrogations not have the right to compel self-incriminatory answers. Whether the result is reached by pointing

The privilege is not ordinarily dependent upon the nature of the proceeding in which the testimony is sought or is to be used. It applies alike to civil and criminal proceedings, wherever the answer might tend to subject to criminal responsibility him who gives it.

ld. at 40 .

35. Hopefully, this contention was made for the last time in the Miranda oral arguments. Unofficial Transcript of Oral Argument, p. 101 (Mr. Siegel on behalf of respondent in Vignera $v$. New York), on file in University of Michigan Law Library.

36. Traynor, The Devils of Due Process in Criminal Detection, Detention, and Trial, 21 RECORD of N.Y.C.B.A. 357, 372 (1966).

37. McNaughton, The Privilege Against Self-Incrimination: Its Constitutional Affectation, Raison d'Etre and Miscellaneous Implications, in POLICE POWER AND INdividual Freedom 223, 237 (Sowle ed. 1962).

38. Id, at 241 . 
out the elementary fact that police have not been given the authority to compel disclosures of any kind or whether the result is put on the ground that the person questioned is "privileged" not to answer makes little difference. Answers should not be compelled by police. . . . ${ }^{30}$

(4) There is nothing very new or unusual about the problem which confronted the Court in Miranda; there is nothing really startling or inventive about the solution. I think it may fairly be said that the police station is the third field on which the basic issue in Miranda has been fought. The force of the privilege, or radiations from it, led (in the seventeenth century) to the abolition of judicial interrogation at the trial itself, and (in the nineteenth century) to the disappearance of interrogation at the preliminary examination as well. These developments occurred at a time when "local prosecuting officials were almost unknown"40 and a "primitive constabulary ... consisting of watchmen rather than police officers and wanting in any detective personnel, attempted little in the way of interrogation of the persons they apprehended." 41 Eventually, "but wholly without express legal authorization," 42 interrogation became the function of the emerging organized police and prosecuting forces. Moreover, I think it plain that the last stand will not be made in the stationhouse. By defining "custodial questioning" to mean "questioning initiated by law enforcement officers after a person has been taken into custody or otherwise deprived of his freedom of action in any significant way," 43 the $M i$ randa Court seemed to anticipate still other battlefields-the squad car, the streets, public places, and even homes.

That over the centuries this problem has been popping up in different settings strongly indicates that the Miranda Court did not,

39. Id. at 237-38.

40. Mayers, Shall We Amend the Fifth Amendment? 86 (1959).

41. Ibid. See also Barrett, Police Practices and the Law-From Arrest to Release or Charge, 50 CALIF. L. REv. 11,16 n.29 (1962).

In England, "it was not until 1842, thirteen years after the formation of the Metropolitan Police, that a small body was detached for detective work, and not until 1878 that the Criminal Investigation Department was formally created." DevLIN, The Criminal Prosecution in England 18 (1959).

"In America the history of preliminary examination follows a course parallel to that run by the English institution whence it was derived." Kauper, Judicial Examination of the Accused-A Remedy for the Third Degree, 30 MicH. L. REv. 1224, 1235 (1932).

42. MAYERs, op. cit. supra note 40 , at 87 .

43. 384 U.S. at 444. The "significant" in "deprived of his freedom of action in any significant way" does not appear to be very significant, for at two other places the Court drops this qualification of deprivation of freedom constituting custodial questioning. Id. at 477,478 . 
and did not need to, invoke a "new" fifth amendment. This history, however, is also consistent with the view that we cannot, never could for very long, and never will be able to live with the "old" one. It may be that in this area of the law we cannot do what we have done with respect to Brown v. Board of Education ${ }^{44}$ and Baker $v$. $\mathrm{Carr}_{,}{ }^{45}$ namely take our ideals down from the walls where we have kept them framed "to be pointed at with pride on ceremonial occasions,"46 and "put flesh and blood" on them and "look them in the teeth." 47 But this goes to Miranda's hope of posterity, not to its pride of ancestry.

44. 347 U.S. 483 (1954).

45. 369 U.S. 186 (1962)

46. Schaefer, Comments [on Kamisar, Has the Court Left the Attorney Behind?, 54 Ky. L.J. 464 (1966)], 54 Ky. L.J. 521, 524 (1966). This symposium was held six months before Miranda was handed down.

47. Ibid.

Justice Schaefer also said, it should be noted, that "if the ideals are too broadly stated to meet essential practical objectives then $I$ would suggest that the ideals must be modified and that we ought to be frank." Id. at 524. He indicated, further, that this might well be the case with respect to police interrogation:

When it is suggested that the right to counsel be projected into the station house, there is an immediate response. Many voices answered-some stridently, but I think none more eloquently than [fellow-panelist] Mr. Kuh answered this morning-saying that it is not possible to enforce criminal law unless station house interrogation in the absence of counsel is permitted. I think I share that view, but I don't know. . . . There just isn't anything very worthwhile to indicate what has happened and what would happen if station house interrogation were not permitted save in the presence of counsel. It scares me, but I don't know. Id. at 523 .

Miranda, however, does not "fully project" counsel into the stationhouse-at least not to the degree desired by some ACLU spokesmen. On learning of the Miranda decision, the executive director of the national group, John de J. Pemberton, Jr., tempered his enthusiasm by voicing "regret that the Court did not take the final step of stating that the privilege cannot be fully assured unless a suspect's lawyer is present during police station interrogation." N.Y. Times, June 14, 1966, p. 25, col. 1. Similarly, the director of the New York chapter (Aryeh Neier) commented: "[Miranda] doesn't go far enough in protecting those who most need protection. We do believe that a person must have the advice of counsel in order to intelligently waive the assistance of counsel." Ibid.

To say that Miranda does permit some stationhouse questioning in the absence of counsel-if a duly advised suspect intelligently waives his right to the assistance of counsel-is not to quibble. Not if, as Los Angeles District Attorney Evelle Younger concluded (after surveying more than 1,000 post-Miranda cases, in fully half of which the defendant had made an incriminating statement): "Large or small, . . . conscience usually, or at least often, drives a guilty person to confess. If an individual wants to confess, a warning from a police officer, acting as required by recent decisions, is not likely to discourage him." Office of the District AtTorney, County of Los Angeles, Results of Survey Conducted in the District Attorney's Office of Los angeles County Regarding the Effects of the Dorado and Miranda Decisions Upon the Prosegution of Felony Cases 4 (Aug. 4, 1966) (copy on file in the University of Michigan Law Library). See also Brief for United States, p. 30 n.20, Westover v. United States, 384 U.S. 436 (1966): "[T]he great majority of clear admissions or confessions are prompted either by conscience, by a desire to get the matter over with, or by a calculated design to secure more favorable treatment."

But see Address by Richard H. Kuh of the New York Bar, Eighteenth Annual 


\section{I. "No Significant Support in . . History . . . OR . . LANGUage"}

The Miranda majority's application of the privilege against selfincrimination to police interrogation, insists dissenting Justice White, "has no significant support in the history of the privilege

Meeting of the Conference of Chief Justices, Aug. 5, 1966, pp. 1, 4 (copy on file in the University of Michigan Law Library):

If we are to be logical and intellectually honest, we must recognize there is rarely such a thing as Miranda contemplates-an intelligent, voluntary waiver of the Fifth Amendment privileges. . . Had the United States Supreme Court recognized what I think is clear-at least the improbability, if not the impossibility, of an intelligent waiver of the Fifth Amendment privilege-the judges might have squarely wrestled with the issue and said: Confessions are no longer usable in our adversary system."

To the same effect is Nedrud, The New Fifth Amendment Concept: Self-Incrimination Redefined, 2 NAT'L Dist. ATr'ys Ass'N J. 112, 113 (1966), maintaining that "certainly, under the requirements of the [Miranda] Court, no one in his 'right mind' would waive such rights."

Whether suspects are continuing to confess because they don't understand the whole "formula" or because the police are "stretching the truth" when they claim they give the full warning, or because the promptings of conscience and the desire to get it over with are indeed overriding the impact of the warning, the fact remains that they are continuing to confess with great frequency-which would not have been the case if the Court had adopted the position taken by the aforementioned ACLU spokesman. Even Brooklyn District Attorney Aaron Koota, who has charged that the new rulings have "shackled" law enforcement, N.Y. Times, Aug. 13, 1966, p. 1, col. 2, claims that only $40 \%$ of major felony suspects have refused to make statements after being warned of their rights. N.Y. Times, Sept. 5, 1966, p. 17, col. 1. Mr. Koota reported a sharp increase of refusals to talk after Miranda, but the commanding officer of one Manhattan detective squad reported that "by and large, they [suspects] readily admit what they've been doing even after they've been told of their rights." N.Y. Times, June 25, 1966, p. 1, col. 3. And Mr. Younger disclosed that "the percentage of cases in which confessions or admissions were made has not decreased, as might have been anticipated, because of the increased scope of the admonitions required by Miranda." Los ANGeles SURVEY, op. cit. supra, at 3.

The Miranda Court required enough things "at one gulp," for me at any rate, cf. 384 U.S. at 502 (Clark, J., dissenting), but a rule that a suspect needs counsel to waive counsel is by no means unthinkable. The "waiver" standards are designed for judicial proceedings; no judge presides in the stationhouse. In oral argument, Justice Stewart raised the possibility that a suspect could not waive his constitutional rights without the advice of counsel and petitioner agreed "that this is the worst place for waiver" because "the party alleging waiver has control of the party alleged to have waived." Unofficial Transcript of Oral Argument in Miranda and Companion Cases, p. 84 (oral argument of Mr. Earle for petitioner in Vignera v. New York), on file in University of Michigan Law Library. See also id. at 73. However, the Miranda opinion does not explicitly consider this possibility. The ACLU amicus brief, on the other hand, does not explicitly consider any other possibility. Rather, as I read it at any rate, the ACLU contends that effectuation of the privilege requires the "presence of counsel" (emphasis added), a phrase it employs a dozen times, Brief for ACLU as Amicus Curiae, pp, 3, 4, 9, 22-25, 27-28, 33, not merely advice as to the immediate availability of counsel, a reading which finds support in the post-Miranda comments of the ACLU spokesmen, N.Y. Times, June 14, 1966, p. 25, col. 1. The failure of the Court to deal explicitly with (if only to reject) the ACLU contention is surprising, for in all other respects the ACLU amicus brief presents "a conceptual, legal and structural formulation that is practically identical to the majority opinion-even as to use of language in various passages of the opinion." Dash, Foreword to Medalie, From Escobedo to Miranda: The Anatomy of a SuPREMe Court Decision xvii (1966). 
or in the language of the Fifth Amendment." 48 The first authority he cites is the late Professor Edmund M. Morgan, who said that "there is nothing in the reports to suggest that [the rule excluding coerced confessions] . . . has its roots in the privilege against selfincrimination. And so far as the cases reveal, the privilege, as such, seems to have been given effect only in judicial proceedings, including the preliminary examinations by authorized magistrates." 49

For Justice White to lead with Morgan is a bit puzzling, since further along in this same article Professor Morgan points out:

The function which the police have assumed in interrogating an accused is exactly that of the early committing magistrates, and the opportunities for imposition and abuse are fraught with much greater danger. . . . Investigation by the police is not judicial, but when it consists of an examination of an accused, it is quite as much an official proceeding as the early English preliminary hearing before a magistrate, and it has none of the safeguards of a judicial proceeding. If the historical confines of the privilege are to be broadened, this surely is an area that needs inclusion for reasons infinitely more compelling than those applicable to the arraignment.

Mr. Wigmore himself declares that the protection of the privilege "extends to all manner of proceedings in which testimony is to be taken, whether litigious or not, and whether 'ex parte' or otherwise. It therefore applies in . . . investigations by a legislature or a body having legislative functions, and in investigations by administrative officials." If so, how can testimony taken by the police be excluded?50

\section{Continues Justice White:}

Our own constitutional provision provides that no person "shall be compelled in any criminal case to be a witness against himself." These words, when "[c]onsidered in the light to be shed by grammar and the dictionary appear to signify simply that nobody shall be compelled to give oral testimony against himself in a criminal proceeding under way in which he is a defendent." Corwin, The Supreme Court's Construction of the Self-Incrimination Clause, 29 Mich. L. Rev. 1, 2. And there is very little in the surrounding circumstances of the adoption of the Fifth Amendment or in the then existing state constitutions or in state practice which would give the constitutional provision any broader meaning. Mayers,

48. 384 U.S. 436,526 (1966).

49. Ibid., quoting Morgan, The Privilege Against Self-Incrimination, 34 MinN. L. REv. 1,18 (1949).

50. Morgan, supra note 49, at 27-28, 29. (Emphasis in the original.) 
The Federal Witness' Privilege Against Self-Incrimination: Constitutional or Common-Law?, 4 American Journal of Legal History $107(1960) .^{\text {s1 }}$

However, the Corwin article relied upon by Justice White does call attention to a circumstance surrounding the adoption of the fifth amendment which suggests that the constitutional provision is entitled to a broader meaning:

The result [in late seventeenth century England of the extension from civil to criminal cases of the rule that a party is not a competent witness on account of interest] was that henceforth the mouth of an accused ... . was closed whether for or against himself; and it is in this form that the immunity of accused persons passed to the American colonies balanced, that is, by the corresponding disability. Not until 1878, following a similar reform in several of the states, was the right to testify in their own behalf, under oath, accorded defendants in the national courts.

[S]ince the [federal and early state] constitutional provisions ... did not overrule the common law in excluding an accused from the witness stand, their stipulation for his immunity taken by itself becomes pointless. If only, therefore, to save the framers of these provisions from having loaded them with a meaningless tautology, their language had to be given other than its literal significance ....52

What does this immunity of the accused at that time signify? "Therefore," Dean Griswold argues, "the importance of the privilege against self-incrimination [at that time] . . . was in investigations, in inquiries, and with respect to questioning of the defendant by the judge in criminal cases, such as had been made notorious by Judge Jeffries." 53 According to Professor Mayers, however, the implications from the accused's incompetence to testify need not and should not carry us so far. He maintains that the privilege is not available to a mere witness, but only to an "accused," and that the privilege is given sufficient content and meaning if it is viewed as protecting an accused not sworn as a witness from interrogation by prosecutor or judge at the trial (a practice which continued in England into the eighteenth century and in New York, at least, as late as the Revolution), or as protecting an accused from questioning before trial. $^{54}$ In the same article invoked by Justice White, Professor Mayers makes these points:

51. 384 U.S. at 526.27.

52. Corwin, The Supreme Court's Construction of the Self-Incrimination Clause, 29 Mich. L. REv. 1, 11-12.

53. Griswold, The Individual and the Fifth Amendment, The New Leader, Oct. 29, 1956, pp. 20, 22.

54. 4 AM. J. Legar Hist. 114 n.20 (1960). 
The possibility that Madison and Ellsworth (the latter the chairman of the Senate committee responsible for these changes in arrangement) may have had chiefly in mind the protection of the accused (and of the suspect not yet charged) from pre-trial questioning, rather than from questioning at the trial, is enhanced by the fact that the acccused was not at that time (or for nearly a century thereafter) a competent witness at his trial .... [I]f one concedes, arguendo, that the protection of the accused on trial was not the object, it does not follow, as seems to be assumed, that the purpose of the provision must have been to protect the witness. It could just as well have been intended to protect the accused or the suspect before trial. It is perhaps relevant that Madison's own state had had experience with oppressive questioning of suspects by the royal governor just before the Revolution. ${ }^{55}$

In 1833 appeared Story's monumental treatise [apparently the first treatise on the Constitution which discusses the privilege]. . . . His discussion of the self-incrimination clause of the Fifth Amendment discloses a complete unawareness of its application to the witness, and seems indeed to confine the intention of the provision to the accused in the pretrial stage-to stress the protection against executive oppression of the accused. ${ }^{\text {s }}$

Professor Mayers, one may fairly conclude, is bent on overruling Counselman $v$. Hitchcock, not on precluding Miranda v. Arizona. Professor Mayers, I think it fair to say, regards the application of the privilege to legislative investigations as a much sharper departure from the understanding of the draftsmen who framed the self-incrimination provision, the Congress which proposed it and the state legislatures which ratified it, than the application of the privilege to police interrogation.

If for no other reason than that there were no professional police either in England or America when the privilege was drafted and ratified, or at least the police had not yet assumed the functions of criminal investigation, the extent to which Miranda marks a departure from the "original understanding" will probably never be

55. Ibid. (Emphasis in the original.)

56. Id. at 121. (Emphasis in the original.)

Professor Mayers is referring to 3 STORy, Commentaries on the Constitution of THE UNITEd STATES \& 1782 (1833):

[The privilege against self-incrimination] also is but an affirmance of a common law privilege. But it is of inestimable value. It is well known, that in some countries, not only are criminals compelled to give evidence against themselves, but are subjected to the rack or torture in order to procure a confession of guilt. And what is worse, it has been (as if in mockery or scorn) attempted to excuse, or justify it, upon the score of mercy and humanity to the accused. It has been contrived, (it is pretended,) that innocence should manifest itself by a stout resistance, or guilt by a plain confession; as if a man's innocence were to be tried by the hardness of his constitution, and his guilt by the sensibility of his nerves. 
fully settled. This is not to say, however, that a sketch of the history of pre-police interrogation is unilluminating.

To begin at what should be a sufficient starting point for our purposes, justices of the peace in England were empowered by the middle of the fourteenth century "to take and arrest all those that they may find by indictment, or by suspicion and to put them in prison." 67 Two centuries later, the emergent practice of making some kind of examination of suspects before committing them for formal accusation was legalized by the Statutes of Philip and Mary (1554-55).58 The "object" of these statutes was "to expose and detect a man assumed to be guilty"; 59 pursuant to them "a justice of the peace really acted as police, constable, detective, prosecuting attorney, examining magistrate and complaining witness." 60 By the beginning of the eighteenth century, writes Professor Kauper, "the spirit" of the now fully established rule against self-incrimination "must have been carried over to the preliminary examination, for in this examination there was evident a gradual abandonment of judicial interrogation of the accused. The practice developed of taking only a voluntary statement by the accused after cautioning his as to his rights ... [The] practice was developing of permitting the accused to have counsel at this examination."61 The Statutes of Philip and Mary were formally repealed in $1848,{ }^{62}$ but "long before" that, the "inquisitional preliminary examination . . . had sunk into oblivion and a purely judicial inquiry had supplanted it." 63

In America, the history of preliminary examination ran a parallel course. Colonial magistrates "rigorously examined persons suspected of crime . . . after the manner of the English justice of the peace."64 In 1641, "when the [Massachusetts] colony was troubled by a wave of vicious criminality [when wasn't there a 'crime crisis'?], Governor Bellingham consulted the elders of the New England churches on the question 'how far a magistrate might exact

57. The Justices of the Peace Act, 1360, 34 Edw. 3, c. 1.

58. 1 \& 2 Phil. \& M., c. 13, \& 4 (1554); 2 \& 3 Phil. \& M., c. 10, § 2 (1555); see Molex, Our Criminal Courts 15 (1930).

59. 1 Stephen, a History of the Criminal Law of England 221 (1883).

60. Kauper, Judicial Examination of the Accused-A Remedy for the Third Degree, 30 MICH. L. REv. 1224, 1233 (1932). See generally 5 Holdsworth, A History of ENGLISH LAw $191-92$ (1924); Grant, Our Common Law Constitution, 40 B.U.L. Rev. 1, 10-12 (1960); 1 STEPHEN, op. cit. supra note 59, at 221-25.

61. Kauper, supra note 60 , at 1233-34.

62. I1 \& 12 Vict., c. 42 , \& 18 (1848).

63. Kauper, supra note 60 , at 1234 .

64. Haskins, Law and Authority in Eariy Massachusetis 174 (1960). 
a confession from a delinquent in capital cases?" "65 In their study of colonial New York, Goebel and Naughton, citing examples largely from the early and middle eighteenth century, reported "numerous cases where the minutes reveal the reading at the trial of a prisoner's confession. It had to be proved by the magistrate who took it, but otherwise no further formalities were observed." 66 They point out that "although a confession could only be introduced if not made under oath, it would serve to convict without corroborating evidence, if the defendant had pleaded not guilty in open court." 07 Since the felony defendant conducted his own defense and was thus

directly vulnerable to questioning from the bench . . . the most dangerous juncture at a trial for the defendant-counsel was the moment when the Crown introduced a confession taken by a justice at a preliminary hearing. . . . Obviously if a defendant had any remarks to make about his earlier words, he would likely find himself answering questions from the bench [and] . . . where he had made more than one preliminary statement and had contradicted himself, the introduction of all the "confessions" would tempt him to unguarded speech, or he might be asked to explain. ${ }^{68}$

Although the transference of criminal investigation functions from magistrates to police did not occur as sharply in this country as it did in England, ${ }^{69}$ and there were forces other than the use of the privilege which were inimical to a magistrate's exercise of police functions in America, ${ }^{70}$ it may be said that "the establishment of the rule against self-incrimination, with its significant reaction in England resulting in abolition of the practice of interrogating the accused, had the same effect in the American colonies. Formal constitutional recognition of the rule contributed to the tradition already accumulating against exercise of inquisitorial powers by the magistrate or justice of the peace."71 It may also be said that "if

65. Id. at 201.

66. Goebel \& Naughton, Law Enforgement in Colonial New York 654 (1944).

67. Id. at 653 .

68. Id. at 653-54.

69. See Barrett, Police Practices and the Law-From Arrest to Release or Charge, 50 CaLif. L. Rev. 11, 17 n.39 (1962).

70. Professor Pound points to "the idea of separation of powers, so much insisted on in the American polity," which "judicialized" the preliminary examination "before the institution of a modern police had developed, and so left a gap which in practice had to be filled outside of law." Pound, Criminal Justice in America 88 (1929). Professor Moley, however, suggests that in many American communities there may not have been much of "a gap," commenting that "the early development of the county prosecutor as an aggressive agent of law enforcement, and the power and prestige of the sheriff in all frontier communities, probably prevented the justice of the peace and the city magistrates from assuming much importance as investigators of crimes and suspected criminals." MOLEY, op. cit. supra note 58, at 20.

71. Kauper, supra note 60 , at 1236. 
the police are permitted to interrogate an accused under the pressure of compulsory detention to secure a confession . . . they are doing the very same acts which historically the judiciary was doing in the seventeenth century but which the privilege against self-incrimination abolished." 72 In this connection it is quite instructive, I believe, to turn to mid-nineteenth century criticism of judicial "examination" in New York, where that practice survived, relatively late, until that time. Indeed, the analysis of the alleged evils in and suggested remedies for the "examination" as spelled out by the Commissioners on Practice and Pleading ${ }^{73}$ in the course of submitting their proposed Code of Criminal Procedure to the New York Legislature in the year 1849 so strikingly parallels the Miranda discussion-if we but substitute "interrogation" for "examination" and "police" for "magistrate"- that I cannot resist the temptation to quote from that remarkable report at length: ${ }^{74}$

... [I]n the early stages of the accusation,-when he is hurried before a magistrate upon a charge of which he may be innocent, and of which, even if it be otherwise, the law has not yet adjudged him guilty,-the first dictate of duty seems to be, to inform [the accused] ... of his rights and to afford him every opportunity to throw around himself the protection of the law. And yet, according to the existing system of practice, upon the idle fiction that every man is presumed to know the law, he is supposed to be informed of the first right secured to him by the Constitution,- that of appearing and defending himself by counsel. If he happens to be ignorant of this, the examination of the case proceeds, and testimony is taken against him which may be illegal in its character, or which, without the substantial opportunity for a cross examination, may in some contingencies be used against him on his trial.

Against this prejudice the Commissioners propose to guard, by requiring the magistrate to inform the defendant of his right to the aid of counsel in every stage of the proceedings, and before any further proceedings are had,--to allow the defendant a reasonable time to procure counsel,- and to send for such counsel in the city or town, as the defendant may name. (Sec. 180, 181.)

In this proceeding [the "examination" by the magistrate], the Commissioners have discovered principles which they deem at war with the rights of the accused. The very term "examination," which

72. Beisel, Control over Illegal Enforcement of the Criminal law: Role of THE SUPREME COURT 104 (1955).

73. The commissioners were David Dudley Field, David Graham and Arphaxed Loomis.

74. Commissioners on Practice and Pleadings, Rep't No. 4-Code of Criminal Procedure xxv, xxvii-xxix (1849). 
is used in the statute, and the proceedings pointed out as the mode of taking it, all seem to be a departure from the spirit of the constitutional declaration, which provides that "no person shall be compelled, in any criminal case, to be a witness against himself." The object of the examination, as it was originally instituted, was, not to place the defendant in the hands of a cross-examining magistrate, who might, according to the principles of the French practice, by the exercise of ingenuity, extract from the defendant evidence of his guilt. But it was designed, in the humane and benign spirit of the common law, to give the defendant an opportunity, by a voluntary explanation, to exculpate himself from the charge. . . .

Instead of his being informed, as the fact is, that [the "examination"] is furnished to him as a shield and is not to be used against him as a sword, he is by a loose course of practice, if no other motive be imputable, led to believe that it is one of the ordinary proceedings against him, having in view the establishment of his guilt. $\mathrm{He}$ is accordingly examined by a series of searching questions, oftentimes proceeding upon the assumption of his guilt, and is driven to the alternative of equivocating as to the facts, or of denying circumstances plainly true, or of what is occasionally his resort, declining to answer. Those who are in the slightest degree conversant with criminal trials, can well attest how successfully the adoption of either of these alternatives, can be used against the defendant on his trial. ...

[T] he Commissioners have proposed to dispense entirely with this examination, and to substitute in its place, what the law designed should alone be furnished, an opportunity to the defendant to make a statement in his exculpation. They accordingly provide, that when the examination of the witnesses on the part of the people is closed, the magistrate shall inform the defendant that it is his right to make a statement in relation to the charge against him; that the statement is designed to enable him, if he sees fit, to answer the charge, and to explain the facts alleged against him:that he is at liberty to waive it,-and that his waiver cannot be used against him on the trial. (Sec. 188.) If he elect to make the statement, it is then to be taken by the magistrate, who, instead of being left at liberty to put every form of question which his ingenuity may suggest, is restricted to asking the defendant general questions as to his age and residence and the like, and to asking him to give any explanation he may think proper, of the circumstances appearing against him, and to state any facts which he thinks will tend to his exculpation. (Sec. 190.) ...

On the other side of the Atlantic, but a year earlier-1848, the very year the Statutes of Philip and Mary were formally repealeda Royal Commission appointed to inquire into the state of the criminal law in the Channel Islands found "objectionable" "the preliminary examinations 'au secret,' and the consequent interroga- 
toire of the accused," 75 despite the fact that "the present practice ... requires that [the prisoner] be told that he cannot be compelled to answer the questions of the Court, and that what he says will be used against him at the trial."76 Again, the Commissioners' comments on the relationship between the "right of silence" and the right to counsel have obvious application to the Miranda controversy: ${ }^{77}$

[The prisoner] is not allowed the assistance of Counsel, who would probably advise him not to answer. Such a privilege would amount to the abolition of the interrogatoire. In truth, a voluntary interrogatoire is a contradiction; and the compulsion of the process, once physical but still moral, is not the least objectionable part of the system. The caution to abstain from answering, if the party thinks fit, is always given in words; but a prisoner, acting without counsel, will almost always, in practice, feel himself bound to answer. Then the questions put are those which arise from evidence which has been so arranged (and quite properly) as to give the fullest effect to the prima facie case of accusation. The answers given to such questions are given at a great disadvantage; and, probably, this disadvantage is even exaggerated by the prisoner, who is pressed with the circumstances of suspicion marshalled in their most formidable order. Hence arises a temptation to evade and deceive, by which an ignorant person would be seduced, however innocent of the offence charged. Another very dangerous feature in this practice appears to be that its tendency is to engage the Court, which conducts the examination, in a contest with the prisoner....

"It is impossible to deny the efficacy of the present practice as an instrument for the occasional detection of crime," conceded the Commissioners, "but it is equally clear that the practice is liable to mislead, even when administered with the purest intentions."78 "We have no doubt," they hastened to add, "that the members of the Royal Court were perfectly sincere in assuring us that it is often of the greatest use to a prisoner, and that they never knew an innocent man condemned in consequence of it. But it appears to us dangerous to make legal guilt depend upon anything short of proof from extrinsic evidence or the voluntary confession of the accused."79

75. Commissioners on Criminal Law in the Channel Islands, Rep't No. 2 (1848), reprinted in 8 Rep. St. Tr. 1210 (N. S. 1850-58) (App. C).

76. Id. at 1200. This marked "a departure from the old law in Terrien and the Approbation, by which the accused in refusing to answer or not answering pertinently, would be subjected to the torture." Ibid.

77. Id. at 1211-12.

78. Id. at 1212 .

79. Ibid. 


\section{II. "Trained Incapacity" and Those Who Lacked IT}

Why did the fictions exposed in the 1840's have to be exposed anew in the 1960's? Why did the old abuses in new forms so persist and flourish?

For one thing, as I indicated at the outset, the "legal mind" (unhappily) was equal to the task of seeming to reconcile the grim facts with lofty principles: police interrogation-indeed, the "third degree"- - did not violate the privilege because the questioning did not involve any kind of judicial process for the taking of testimony. ${ }^{80}$ This "trained incapacity" (to use Veblen's phrase) to see the problem in the round was long utilized by those who possessed it not only to shut from their minds the de facto inquisitorial system, but also to thwart attempts to mitigate such a system by "formalizing" or "judicializing" it. For example, when, in the early 1940's, a member of the Advisory Committee on the Federal Rules of Criminal Procedure advocated as a cure for the abuses of secret police interrogation a system whereby a judicial officer would question a suspect only after informing the suspect "of his right to the advice of counsel, that he is under no obligation to answer any question, that any answer he chooses to give may possibly be used against him, and that his refusal to answer cannot be used against him," 81 the recommendation was rejected "as being contrary to the basic traditions of Anglo-American criminal procedure, and as probably violative of the constitutional guarantee against self-incrimination." 82 Why basic traditions were honored and self-incrimination problems avoided in the absence of these important safeguards was not made clear. Perhaps this is what Mr. Dooley meant when he told us that he "knowed a society wanst to vote a monyment to a man an' refuse to help his fam'ly, all in wan night."

Some men are brash enough to write books about the law without adequate "legal conditioning." One such man was Ernest J. Hopkins, an official investigator employed by the Wickersham Commission. According to Zechariah Chafee, Hopkins showed "notable skill and enterprise in breaking through the barriers of silence

80. Even those who pointed out that "the private or secret interrogation of arrested persons ... has become ... in many cases the foundation of scandal, harsh criticism and judicial condemnation" conceded that the privilege against self-incrimination "is obviously limited to judicial statements." ALI Code of Criminal Procedure \$ 38, comment at 182 (Tent. Draft No. 1, 1928).

81. FED. R. CRIM. P. 249 (Prelim. Draft 1943) (Professor Waite's proposed Additional Rule 6.1).

82. FEd. R. Crim. P. 253 (Prelim. Draft 1943) (reply memcrandum prepared by Secretary of Advisory Committee). (Emphasis added.) 
which surround official lawlessness."83 However, being a newspaperman by profession rather than a lawyer, Mr. Hopkins showed a notable lack of skill and enterprise in grasping why the privilege against self-incrimination meant so much in the courtroom but so little in the police station. Thus, five years before Brown $v$. Mississippi and thirty-five years before Miranda $v$. Arizona, this "untrained observer" said of the prevailing definitions of the "third degree" (e.g., "rigid and severe examination," "oppressive methods," infliction of "suffering"): 84

[T] hese definitions convey no hint as to the legality or illegality of the basic process or the methods used therein. There is a fundamental right possessed by the American citizen ... set forth in the Fifth Amendment in the following words:

Nor shall any person . . . be compelled in a criminal case to be a witness against himself.

This strikes directly at the heart of the situation; I do not see why one should seek farther than the Constitution for a clear definition of the third degree. The gross unlawfulness of the practice is thus stated by implication:

The third degree is the compelling of a person in a criminal case to be a witness against himself.

The use of the more objective concept of compulsion, borrowed from the Constitution . . . gets us down to the central question, the legitimacy of the pre-trial inquisition itself.

There are a thousand forms of compulsion; our police show great ingenuity in the variety employed. But any and all forms of compulsion, with the object of securing confessions, must violate the constitutional guarantee ... Our police, from the moment a man falls into their hands in an important case, hound him with the persistent demand "Confess." They may use violence and torture or they may not; but in either case the secret police-held grilling or sweating violates the time-honored and peculiarly important restraint by which Americans, and the English before them, have sought to protect themselves against official tyranny.

For those troubled by the spectacle of a man so unfamiliar with prevailing legal reasoning writing a book about the law, it should be pointed out by way of mitigating circumstances that even eminent lawyers have (happily) demonstrated a surprising lack of "trained incapacity" to see the fairly obvious in this area. Take Zechariah Chafee, for example. Chafee knew better. In the early 1930's he had recognized, albeit not been impressed by, the legal

83. Hopkins, Our Lawless Police vii (1931) (Preface).

84. Id. at 193-95. (Emphasis in the original.) 
reasoning which led to the checking of the privilege at the door of the interrogation room. ${ }^{85}$ However, he forgot this a generation later. Indeed, this oversight permeated his defense of the privilege in the 1950's:

There are at least three reasons for the privilege against self-incrimination. In the first place, although it plainly interferes with short-time efficiency by making it harder to discover facts through questioning, the privilege is likely to promote long-time efficiency.

If prosecutors and police could count on grilling a suspect as much as they pleased, they might not take the trouble to build up a solid case from objective proofs. . . .

The second reason for stoutly maintaining the right of every man not to be "compelled . . . to be a witness against himself" is that it protects us from something far worse than answering questions. Nothing else in the Constitution prevents government officials and policemen from extorting confessions. . . .88

Similarly, Dean Erwin Griswold, who wrote a famous little book on the subject, displayed what some might regard as a woeful lack of the requisite special "training":

We may better understand the importance of the Fifth Amendment by considering what not having it would mean .... If we are not willing to let the Amendment be invoked, where, over time, are we going to stop when police, prosecutors, or chairmen want to get people to talk?87

Somewhat surprisingly, in a book billed as "challenging much of the legal folklore which abounds in the discussion of the subject

85. Since the privilege exists during the trial in open court of a person who has been formally charged with crime, it seems even more applicable to the preliminary inquisition of a suspect by police or prosecutors before any judicial proceeding or formal charge. It is true that there is some difference of opinion whether the third degree violates the privilege against self-incrimination; a few courts say that it does not because the questioning does not involve any kind of judicial process for the taking of testimony. This seems a narrow limitation of a constitutional right.

Chafee, Pollak \& Stern, The Third Degree, in National Commission on Law ObserVANGE AND ENFORCEMENT, REPORT ON LAWLESSNESS IN LAW ENFORCEMENT 26-27 (1931).

86. Chafee, The Blessings of Liberty 186, 188 (1956). (Emphasis added.) Chafee maintained that "the partial incorporation of [the self-incrimination] clause in the Fourteenth Amendment has made it possible for the Supreme Court to reverse several state convictions based on coerced confessions . . . Id. at 189. The Court, per Brennan, J., did so look back on the "coerced confession" cases in Malloy v. Hogan, 378 U.S. I (1964). See also Justice Black, joined by the Chief Justice, dissenting in Cohen v. Hurley, 366 U.S. 117, 131 (1961). But it is not easy to see how, under any concept of "hard-core" self-incrimination implicit in due process, the Court could have sustained some of the state confessions it did. See Kamisar, Equal Justice in the Gatehouses and Mansions of American Criminal Procedure, in Criminal Justice IN OuR Time 47-49 (Howard ed. 1965).

87. Griswold, The Fifth Amendment Today 75 (1955). (Emphasis added.) 
by E. N. Griswold,"88 Professor Sidney Hook challenged Griswold (and Chafee) only obliquely on this point. Evidently Professor Hook's abundant "common sense" and wide reading in the law failed to compensate for his lack of "formal legal training." Hook took a dim view of the privilege generally. But he, too, seemed to take for granted its applicability to police interrogation (although, quite understandably, he belittled the protection it had in fact provided up to that time for the person subjected to police questioning):

The use of third degree methods against suspects has always been widespread despite the recognition of the privilege against self-incrimination .... This may be granted and the assertion made that the situation would be much worse if the privilege were not recognized. There seems good reason to doubt this .... Whatever Constitutional protection the privilege against self-incrimination gives in safeguarding [a person] from lawless police officers is given just as effectively by the due process clause of the Fifth and Fourteenth Amendments. Further, even if it were retained to reinforce bulwarks against illegal practices of arresting authorities, its meaning could be so modified as to permit the invocation of the privilege to be cited explicitly by counsel in pleading before bench or jury as relevant evidence in the case.

Dean Griswold insinuates several times that the Fifth Amendment is the most important, if not the only, bar to torture, and that its retention prevents the introduction of police state methods of medieval techniques brought up to date .... [I]n general, as we have seen in commenting on Professor Chafee, all that would be required, even in the complete absence of the Fifth Amendment, would be the right to be questioned only in the presence of coun$s e l$, to cut the ground from under the objection. ${ }^{89}$

There goes Professor Hook, showing his lack of "formal legal training" again. "Common sense" would suggest, as Chafee put it, that "a person accused of crime needs a lawyer right after his arrest probably more than at any other time." these remarks, however, the right to the assistance of counsel was deemed inapplicable to police interrogation because the "criminal prosecution" had not yet begun.

In a sense, conditioning police questioning on the presence of counsel-that, of course, is "all" that Miranda requires-does dis-

88. See inside cover of paperback edition (Henry Regnery Co., 1963).

89. Hook, Common SENSE and the Fifth AMENDMENT 45-46, 58 (1957). (Emphasis added.)

90. Chafee, Documents on Fundamental Human Rights 541 (1952), quoted with approval in Crooker v. California, 357 U.S. 433, 446 (1958) (Douglas, J., dissenting). 
pense with the need for the privilege against self-incrimination at this stage-in the same way that conditioning police "encouragement" on the presence of counsel would dispense with the need for the entrapment defense. But why should the presence of counsel be required and why should we "effectively preclude police questioning-fair as well as unfair-until the accused [is] afforded opportunity to call his attorney" 91 - in the complete absence of the fifth amendment?

As is evidenced by the easy assumptions made years ago by those who (fortunately) never acquired the "trained incapacity" to see the problem, the application of the privilege to police interrogation can be defended as either a logical deduction from the constitutional provision or a practical condition upon its successful operation. Moreover, this approach finds much historical support in the Anglo-American experience with prototypes of modern police interrogation (much more support than can be produced to warrant the application of the privilege to legislative investigations and civil proceedings). ${ }^{92}$ Assuming, arguendo, that in order to give the privilege a reading "as broad as the mischief against which it seeks to guard," 83 the Court did violence to language and history, the assault occurred, in aggravated form, long ago:

Is it not clear that a legislative investigation is not a "criminal case"? What application, then, does the constitutional provision have in such proceedings-or in civil trials, or elsewhere, where persons may be subjected to questioning? This is a question which was raised and answered long ago, so long ago in fact that lawyers tend to take it for granted. But early courts saw that the protection of the amendment itself would be an empty gesture if it was literally applied. For example, if the witness is required to answer self-incriminating questions in a civil trial, or in a legislative investigation, the prosecuting officer can use his answers to provide evidence on which he can be prosecuted or convicted. Even if the prosecuting officer cannot use his testimony itself, he can, from that testimony, learn other facts which he could use in the prosecution .... .

For this reason, courts long ago concluded that if the privilege is to be effective at all it must be given a comprehensive application, and thus must prevent compulsory self-incrimination in any proceeding. This is, indeed, a broad construction of the constitu-

91. See note 104 infra and accompanying text.

92. See, e.g., Mayers, The Federal Witness' Privilege Against Self-Incrimination: Constitutional or Common-Law, 4 AM. J. Legal Hist. 107 (1960); Pittman, The Fifth Amendment: Yesterday, Today and Tomorrow, 42 A.B.A.J. 509 (1956); Williams, Problems of the Fifth Amendment, 24 FordHAM L. REv. 19 (1955).

93. Counselman v. Hitchcock, 142 U.S. 547, 562 (1892), quoted with approval in Miranda v. Arizona, 384 U.S. 436, 459-60 (1966). 
tional language, but it is a construction which has seemed to be required if the basic objective of that language is to be realized. ${ }^{94}$

\section{III. "Necessity" and Other Forces}

What would we say of the argument that the fourth amendment does not apply to arrests and searches made without warrants altogether, but only prohibits the use of evidence seized pursuant to defective warrants? ${ }^{95}$ Does it make any more sense to argue that the fifth amendment does not apply to questioning by agents of the state who lack any kind of judicial process for the taking of testimony, but only governs proceedings involving such process? Moreover, it so happened that the Supreme Court frequently advanced the privilege against self-incrimination as the constitutional basis for the federal exclusionary rule in search and seizure cases during most of the period the privilege was deemed inapplicable to police

94. Griswold, op. cit. supra note 87 , at 54-55.

95. The government came close to making this argument in United States v. Lefkowitz, 285 U.S. 452 (1932), when it contended that general, exploratory searches could be made incident to a lawful arrest, although such power could not be conferred by a search warrant. Brief for the United States, pp. 13, 15, 37 n.6. (Emphasis added):

[T] he principles crystallized in the Fourth Amendment were not intended to limit the right of search and seizure incident to a lawful arrest. . . . Nor, we submit, was the search conducted by the officers in the present case a "general exploratory search" of the kind which the framers of the Constitution intended to prohibit by the Fourth Amendment. The abuse there aimed at was the practice of issuing general warrants without probable cause. The generality prohibited was not primarily the generality of the search actually conducted but the generality of the authority to search without any reasonable basis for belief that crime had been committed. . . . The Amendment does not consist of two sentences with a break after the word "violated." It is all one sentence, and the provision that no warrants shall issue except upon probable cause illustrates what is meant by the provision that the right of the people to be free of unreasonable searches and seizures shall not be violated. "The term 'unreasonable' in the constitutions of the States [identical with the Fourth Amendment] has allusion to what had been practiced before our revolution, and especially, to general search warrants, on which the person, place, or thing was not described."

The government's views did not prevail in Lefkowitz, but there have been occasions when the Court has ruled, in effect, that a search without warrant confers greater authority than a search under warrant. See generally Landynski, SEARCH ANd Seizure AND THE SUPREME CouRT ch. iv (1966).

The government's argument in Lefkowitz was topped by the opinion of the court in Hall v. Commonwealth, 138 Va. 727 (1924), which stated that evidence obtained by an officer acting either without a warrant or under a void warrant was admissible in a criminal prosecution because "we believe the framers of the Constitution of the United States, and of this and other States, merely sought to provide against any attempt, by legislation or otherwise, to authorize, justify or declare lawful any unreasonable search or seizure" and "if an official, or a mere petty agent of the State, exceeds or abuses the authority with which he is clothed, he is to be deemed as acting, not for the State, but for himself only; and therefore he alone, and not the State, should be held accountable for his acts." Id. at 740. (Emphasis in the original.) The grounds advanced in Hall for admitting illegally seized evidence were familiar ones at that time. See Cornelius, SEArch ANd Seizure $\$ 9$ (2d ed. 1930). 
questioning. ${ }^{96}$ If absent legal process the privilege was not supposed to apply, why wasn't the federal government allowed all these years to use evidence obtained by officers who did not bother to get any warrant at all? ${ }^{97}$

The view that police interrogation is not limited or affected by the privilege against self-incrimination because it does not involve any kind of judicial process for the taking of testimony had a great deal more to commend it than merely the inherent force of its "logic" or the self-restraint and tenderness of the exempted class of interrogators. It must have had, in order for it to have been taken so seriously for so long.

Among the forces at work was one of society's most effective analgesics-"necessity," real or apparent. ${ }^{98}$ Its influence may be seen in numerous opinions. Although Justice Jackson recognized, in his much-quoted concurring opinion in Watts $v$. Indiana, that "if the State may . . . interrogate without counsel, there is no denying the fact that it largely negates the benefits of the constitutional guaranty," 99 he was willing to let this "negation" occur for otherwise "the people of this country must discipline themselves to seeing their police stand by helplessly while those suspected of murder prowl about unmolested." 100 Again, the first axiom of Justice Frankfurter's dissertation on police interrogation and confessions in Culombe v. Connecticut is: "Questioning suspects is indispensable in law enforcement."101 "Questioning," as Justice Frankfurter and many others used the term, is a "shorthand" for questioning with-

96. See Landynski, op. cit. supra note 95, at 77. Indeed, Boyd v. United States, 116 U.S. 616 (1886), "the first Fourth Amendment case of real consequence" and, "in the Court's own view [in 1925], the leading case on the subject of search and seizure" (LANDYNSKI, op. cit. supra at 49 ), regarded the privilege against self-incrimination as the constitutional backbone of the exclusionary rule.

97. I am only talking about "consistency" between the approach to searches and seizures and self-incrimination on the one hand, and the approach to confessions and self-incrimination on the other, not addressing myself to the merits of basing the exclusionary rule on the fifth amendment. On the merits, as I have indicated elsewhere, I think there is little to be said for it. See Kamisar, Wolf and Lustig Ten Years Later: Illegal State Evidence in State and Federal Courts, 43 MinN. L. REv. 1083, 1088-90 n.16 (1959).

98. It appears to be relatively easy, however, for a given generation to see how the dangers which gripped a previous generation were "much exaggerated." The point is made in Chafee, Thirty-Five Years with Freedom of Speech, 1 KAN. L. REv. 1, 4-6 (1952).

99. 338 U.S. 49,59 (1949).

100. Id. at 61-62.

101. 367 U.S. 568,578 (1961). There was no majority opinion. See text at notes 155-59 infra. 
out advising the suspect of his rights or permitting defense counsel, friends or relatives to be present. ${ }^{102}$

For the police to persist in interrogating a suspect after denying his specific request to contact his lawyer is unfair and coercive, and any resulting confession should be excluded, contended petitioner in Crooker v. California. ${ }^{103}$ Such a rule, retorted a 5-4 majority of the Court, per Clark, J., "would have a . . . devastating effect on enforcement of criminal law, for it would effectively preclude police questioning-fair as well as unfair-until the accused was afforded opportunity to call his attorney." 104 Had issue been joined? The Court seemed to think so. What the Crooker majority meant to say, I believe, was: We are convinced that precluding (or postponing) police questioning until a suspect's specific request to consult with his lawyer is honored would have a devastating effect on law enforcement (on the eve of Miranda, law enforcement would have been delighted to settle for this); ${ }^{105}$ we must conclude,

102. Justice Frankfurter went on to say:

But if it is once admitted that questioning of suspects is permissible, whatever reasonable means are needed to make the questioning effective must also be conceded to the police. . . . Often the place of questioning will have to be a police interrogation room, [in part] because it is important to assure the proper atmosphere of privacy and non-distraction if questioning is to be made productive. . . Legal counsel for the suspect will generally prove a thorough obstruction to the investigation. Indeed, even to inform the suspect of his legal right to keep silent will prove an obstruction.

367 U.S. at $579-80$.

103. 357 U.S. 433 (1958).

104. Id. at 441.

105. It now appears that (in a number of jurisdictions, at least) recognition of a right to retained counsel per request in Crooker would not have affected then-existing practice very much. Three years ago, Major Robert Murray, then chief of the District of Columbia Police Department, testified that "over the years if a man was arrested and said 'I want a lawyer' he was given an opportunity to call a lawyer," Hearings on S. 486 and H.R. 7525 Before the Senate Committee on the District of Columbia, 88th Cong., 1st Sess. 462 (1963), and that the long-established practice was that when a person said "I want a lawyer,' why there is no use wasting time with him. Just get him a lawyer," Id. at 470. Reporting on the practice in mid-Western cities in the late 1950's, Professor Wayne LaFave disclosed:

[R]etained counsel often do enter a case shortly after arrest and immediately confer with their clients or are present when the case reaches the district attorney's office. In Milwaukee, they may actually sit in on the police interrogation. Indigent suspects are not afforded counsel at these early stages. . . Actually turning away counsel who appears at the station to talk with his client is not a common occurrence.

LaFave, Arrest: The Decision To Take a Suspect Into Custody $393-94$ (Remington ed. 1965).

On the eve of Miranda, law enforcement officers also would have been happy to settle for the four hour "preliminary screening" period proposed by the Reporters for the Model Code of Pre-Arraignment Procedure. See Model Code of Pre-ArraignMent Procedure \& 4.04 (Tent. Draft No. 1, 1966). Less than a decade ago, however, the "dean" of American prosecutors had maintained that "frequently, even fortyeight to seventy-two hours is not enough." Coakley, Restrictions in the Law of Arrest, 52 Nw. U.L. REv. 2, 9 (1957). More recently, a spokesman for the National Sheriff's 
therefore, that absent additional coercive factors, such questioning is "fair."

Other significant factors operating over many decades to freeze the status quo were the invisibility of the process- "no other case comes to mind in which an administrative official is permitted the broad discretionary power assumed by the police interrogator, together with the power to prevent objective recordation of the facts"108_and the failure of influential groups to identify with those segments of our society which furnish most of the raw material for the process. "One of the most powerful features of the Due Process Model," Professor Herbert Packer recently observed, "is that it thrives on visibility. People are willing to be complacent about what goes on in the criminal process as long as they are not too often or too explicitly reminded of the gory details." 107 Society, one might add, does not want to be reminded, does not "want to know about criminals, but it does want them put away, and it is incurious how this can be done provided it is done."108 It stings too much to say it now, for we are too close to it, but someday it will be said of the first two-thirds of the twentieth century: Too many people, good people, viewed the typical police suspect and his interrogator as garbage and garbage collector, respectively. (This is every bit as unfortunate for the officer as it is for the suspect.)

Association thought forty-eight hours was "reasonable", Hearings on S. 486 and H.R. 7525, supra, at 300 (Sheriff Canlis), and the head of the International Association of Chiefs of Police plumped for "at least twenty-four hours, excluding days when courts are not in session," ibid. at 293 (Chief Schrotel).

In the 1963 Senate Hearings, David Acheson, then United States Attorney for the District of Columbia, departed from what might be called "the police-prosecution party line" by testifying that "in some very high percentage of the cases a confession is made if it is going to be made at all, within an hour or two, perhaps three hours after arrest. . . . In the great majority of cases a confession is made fairly promptly after arrest." Hearings on S. 486 and H.R. 7525, supra, at 443. In March of this year, on the eve of the oral argument in Miranda, Chief John B. Layton of the District of Columbia Police Department termed his department's current policy of "limited stationhouse testimony-with an upper limit of three hours"-"helpful." He disclosed that "admissions or statements" from suspects had been obtained in "about half" the criminal cases involving questioning and that "about seventy-five per cent" of these were obtained in one hour or less. Washington Post, March 4, 1966, p. B-2, col. 1. Two days after Miranda was handed down, however, in a statement which "appeared to contradict" his earlier views, Chief Layton pointed to the three-hour maximum on stationhouse questioning as one reason why his department had "closed what he believes to be an all-time low number of cases for Washington." Washington Post, June 15, 1966, p. 22, col. 1.

106. Weisberg, Police Interrogation of Arrested Persons: A Skeptical View, 52 J. Crim. L. C. \& P. S. 21, 44 (1961), reprinted in Police Power and Individual Freedom 180 (Sowle ed. 1962).

107. Packer, Two Models of the Criminal Process, 113 U. PA. L. REv. 1, 64 (1964).

108. MacInnes, The Criminal society, in The Police and the Public 101 (Rolph ed. 1962). 
Moreover, with the inadvertent exception of those who wrote the interrogation manuals (each, I suspect, equal to a dozen law review articles in its impact on the Court), ${ }^{109}$ most law enforcement members and their spokesmen did their best to keep society comfortable and blissfully ignorant. Not too surprisingly, they were much more interested in "sanitizing" the proceedings in the interrogation room than in disseminating the life-size details. As long ago as 1910 (when, everybody now agrees, things were in a terrible state), the President of the International Association of Chiefs of Police assured us:

When the prisoner is taken into private quarters and there interrogated as to his goings and comings, or asked to explain what he may be doing with Mr. Brown's broken and dismantled jewelry in his possession, to take off a rubber-heeled shoe he may be wearing in order to compare it with a footprint in a burglarized premises, or even to explain the blood stains on his hands and clothing, that, hypothetically illustrates what would be called the "Third Degree." ... If a confession, preceded by the customary caution, obtained through remorse or a desire to make reparation for a crime, is advanced by a prisoner, it surely should not be regarded as unfair . . . . Volunteer confessions and admissions made after a prisoner has been cautioned that what he states may be used against him, are all there is to the so-called "Third Degree." . . .110

109. The American Civil Liberties Union briefs amicus curiae in Escobedo and Miranda quote extensively from these manuals. Indeed, the Miranda brief reprints a full chapter from O'Hara, Fundamentals of Criminal Investigation (1959). In turn, the majority opinion in Miranda devotes six full pages, 384 U.S. at 449-54, to extracts from various police manuals and texts "which document procedures employed with success in the past, and which recommend various other effective tactics," id. at 448.

Although such manuals had been available for many years, e.g., KIDD, PoLICE INTERrogation (1940) and Mulbar, INTERROgation (1951), so far as I can tell neither law review articles nor Supreme Court briefs made much use of them until quite recently. As late as 1964 most of these manuals were not to be found in the libraries of at least two of our greatest law schools. Perhaps the first law review writer to make extensive use of these texts was Bernard Weisberg of the Chicago bar (see note 106 supra), who later turned up as one of the ACLU lawyers in the Escobedo case.

Two weeks after Miranda was handed down, Thomas C. Lynch, the Attorney General of California, in Washington for a meeting of the National Crime Commission of which he is a member, reported that a preliminary survey indicated "wide use" in his state of the police interrogation manuals criticized by the Court. He disclosed that he was considering a "purge" of all such manuals. Washington Post, June 30, 1966, p. E2, col. 3. Professor Philip Zimbardo, who made the strong charge that "it is my professional opinion as a psychologist who has been concerned with the experimental modification of attitudes and behavior that these techniques [those illustrated in the manuals] represent a highly sophisticated application of psychological principles which for many people are more compelling and coercive than physical torture" (Zimbardo, "An Analysis of Pre-Arraignment Interrogation Techniques and Their Psychological Implications," p. 26, paper read at American Psychological Association Meeting, Sept. 3, 1966), reported that he had "verified that these manuals are used in training interrogators by calling several police academies," id. at 10.

110. Major Sylvester's comments are reported in Larson, Present Police and Legal Methods for the Determination of the Innocence or Guilt of the Suspect, $16 \mathrm{~J}$. Crim. 
As recently as July of this year, the veteran special agent of the Kansas Bureau of Investigation, Alvin A. Dewey, of In Cold Blood fame, told the Senate Sub-committee on Constitutional Amendments:

What is wrong with an officer exercising persistence and patience or showing confidence? Isn't that what any good salesman demonstrates in selling insurance or a car? And a law enforcement officer should be a good salesman in selling a suspect on telling the truth, proving his innocence or guilt. But a salesman cannot do his job if a competitor is standing by, and that is the situation for the law enforcement officer with the presence of an attorney while interrogating a suspect.

As to the description of an interrogation room, I wish to define it as a room where people can talk in privacy which is nothing more than an attorney desires in talking to his client or a doctor in talking to his patient... . [These rooms] bear no resemblance to torture chambers as some may wish to think, and in fact some are equipped with air conditioning, carpeting, and upholstered furniture.111

What I have said so far does not fully account for the persistence of the de facto inquisitorial system. In the late 1920's and early '30's, complacency about the system was shaken-at least for a while-by the notorious cases of Ziang Sun Wan $v$. United States ${ }^{112}$ and People v. Doran ${ }^{113}$ and by the shocking disclosure of the Wickersham Commission. ${ }^{114}$ Still the system survived. Why? Probably because, in addition to the factors I have already mentioned, the practice had become so widespread and intrenched by this time that even most of its critics despaired of completely uprooting it in the foreseeable future. A broad, fundamental attack on the system might well have failed completely; elimination of the more aggravated forms of coercion commanded a high priority and alone appeared feasible. In this regard, the pessimistic views of Zechariah Chafee, co-author of the famous report to the Wickersham Commission on "the third degree,"115 are instructive:116

L. \& Criminology 219, 222-25 (1925) and reported in part in 3 Wigmore, Evidence 316-17 (3d ed. 1940).

111. Statement of Alvin A. Dewey before the Subcommittee on Constitutional Amendments of the Senate Committee on the Judiciary, July 21, 1966, p. 2 (mimeo.) (on file in the University of Michigan Law Library).

112. 266 U.S. 1 (1924). See text at notes $188-89$ infra.

113. 246 N.Y. 409 , 159 N.E. 379 (1927). See text at notes 190-92 infra.

114. National Commission on Law Observance and Enforcement, Report on LawLessNess in LAW ENFORCEMENT (1931) (Wickersham Report).

115. See note 85 supra.

116. Chafee, Remedies for the Third Degree, Atlantic Monthly, Nov. 1931, pp. 621, 
Big jumps in policy may be unattainable or undesirable. [What would Chafee have said of Escobedo and Miranda?] Bad as the third degree is, we should be very cautious about disrupting the police department and the courts in the hope of abolishing it.

Let us begin by considering two simple remedies which are free from the foregoing objections.

The first is to shorten this danger period by obtaining the prompt production of the prisoner before a magistrate, after which he should be out of the hands of the police. This is the situation in Boston, and appears to contribute to the virtual nonexistence of the third degree in that city . . . . There is no opportunity for protracted interrogations lasting over several days and nights, which are common in cities where production in court is illegally delayed. Violence is less probable when scars will not have time to heal before the magistrate sees the prisoner next day. This remedy involves no new law; practically all states require prompt production in court. It introduces no startling innovation in police methods, but merely hastens an act which the police are accustomed to perform. Of course, enforcement of this law will not always be an easy matter. The same motives which cause the police in many cities to investigate brutally also lead them to prolong the time of investigation illegally. However, excessive length of confinement is an offense which the judges can discover and correct more easily than secret coercion ....

Secondly, official records should be kept of the exact time of arrest and of detention; of the transfers of prisoners and the places to which they are taken; of interviews by the police with prisoners and the time interrogations begin and end; and (as in Boston) of injuries to prisoners found visible during a daily examination. Facts of this nature fit naturally into the records customarily kept in police stations and jails.

The two remedies just recommended have the advantage of forming a natural part of the existing routine of police stations and magistrates courts ....

In England, the police are forbidden to interrogate a suspect after his arrest or involuntary detention; thus there is no danger of their using brutality or other pressure to obtain the desired answers . . . . However, it is doubtful if this remedy could be successfully transferred to the United States, at least in the near future .... American police officials ... attach extreme importance to the questioning of arrested persons. They would consider the adoption of the English rule a serious crippling of their activities, and until they feel otherwise it would only be one more law which they would be tempted to violate. How could they be forced to obey it? $I t$ is hard enough to prevent policemen from using physical violence on suspects; it would be far harder to prevent them from asking a few 
questions. We had better get rid of the rubber hose and twenty-four hour grillings before we undertake to compel or persuade the police to give up questioning altogether.

[The remedies recommended in this article] require no constitutional amendments and no legislation, so that their adoption involves no long delay. But immediate success must not be expected. The third degree is deeply rooted in official habits in many cities, and is not likely to disappear entirely until the officials have been persuaded that it is bad and unnecessary.

\section{The $M c N a b b$-Anderson Briefs: The Government Agrees}

That the Privilege Applies to Police Interrogation, But . . .

Until Miranda at least, very few of our states adopted the "simple" and relatively modest remedy of "shortening the danger period" by obtaining the prompt production of the prisoner before a magistrate. ${ }^{117}$ However, a dozen years after Professor Chafee wrote the aforementioned article the Supreme Court did resort to this remedy, as is well known, in the exercise of its supervisory powers over the administration of federal criminal justice. ${ }^{118}$ Neither the opinion of the Court nor the briefs of counsel contain citations to the Chafee article, but the $M c N a b b$ opinion reads as if its author, Justice Frankfurter, had perused the writings of his former colleague more than once.

One would never know it in the midst of all the beating of breasts and gnashing of teeth ${ }^{119}$ which greeted both $M c N a b b$ and the Mallory case ${ }^{120}$ which reaffirmed it, but (as the Chafee article plainly indicates) the new federal rule marked a "compromise" between the objectionable existing practice and the "drastic proposals" then being advanced. That $M c N a b b$ was a "compromise" became quite apparent ${ }^{121}$ in the wake of Escobedo, but it had not escaped

117. In most instances, the courts have not even discussed whether in-custody investigation by the police is legal, concentrating instead on determining the point at which the police have gone too far in their interrogation practices so that the confessor should be regarded as coerced. In the few cases where the issue of illegality has been pressed, most state courts have refused to follow the federal courts in excluding evidence obtained during periods of illegal delay and hence have not needed to mark out the boundaries of proper police conduct short of that extreme characterized as coercion.

Barrett, Police Practices and the Law-From Arrest to Release or Charge, 50 CALIF. L. Rev. 11, 22 (1962). See also Schaefer, Comments [on Kamisar, Has the Court Left the Attorney Behind?, 54 KY. L.J. 464 (1966)], 54 KY. L.J. $521-22$ (1966).

118. McNabb v. United States, 318 U.S. 332 (1943).

119. See generally Hogan \& Snee, The McNabb-Mallory Rule: Its Rise, Rationale and Rescue, 47 Geo. L.J. I (1958); Note, 68 YALE L.J. 1003 (1959).

120. Mallory v. United States, 354 U.S. 449 (1957).

121. Shortly after Escobedo was decided, two former federal prosecutors proposed a combination of the $M c N a b b-M a l l o r y$ rule and objective recording of all question- 
the government lawyers who argued $M c N a b b$ and the companion case of Anderson $v$. United States. ${ }^{122}$ Although they had urged the Court not to "hold inadmissible a confession made during the subsistence of any unlawful practice regardless of whether the confession was voluntary,"123 the government lawyers devoted more space in their brief to "an even more extreme" possibility:

We submit also that the Court should not adopt an even more extreme rule requiring the exclusion of confessions obtained during cross-examination of persons in the custody of the police. The shocking conditions revealed by appellate court decisions and by the researches of investigators naturally give rise to the suggestion that the evils must be ended by abolishing the system of police examination which lies at the root of the evils. The ability to use as evidence confessions obtained by cross-examination is said to lead a lax police force to rely upon confessions and not upon sound investigatory techniques in tracing clues and uncovering evidence. Similarly it is suggested that proper interrogation too easily becomes bullying and bullying becomes brutality. The evil effects of the resulting "third degree" upon the whole system of law observance and law enforcement can scarcely be exaggerated. Finally, proponents of this view point to the low rate of crime and high rate of crime detection in Great Britain where, apparently, the police are not permitted to interrogate a prisoner except to clarify a volunteered statement. ${ }^{124}$

Some of the reasons advanced by the government to stay the Court's hand in $M c N a b b$ and Anderson sound very much like the reasons urged by the federal and state governments a quarter-century later in Miranda: ${ }^{125}$

If a remedy is needed in addition to existing sanctions, the remedy should be administrative or legislative but not judicial. Two reasons support this conclusion. First, the courts are ill equipped to make the investigation necessary before the settled principles may be overturned. Second, the courts have no discretion in the choice of a remedy. The administrative officials may prescribe and enforce regulations designed to protect prisoners against the "third

ing at places controlled by the police as a "more workable and less drastic means" of controlling interrogation abuses than the presence of counsel at these sessions. Enker \& Elsen, Counsel for the Suspect: Massiah v. United States and Escobedo $v$. Illinois, 49 Mins. L. REv. 47, 85 (1964).

122. 318 U.S. 350 (1943). Although today $M c N a b b$ is the much more famous case, the government used its brief in Anderson as the vehicle for extended treatment of the problem.

123. Brief for United States, pp. 49-50.

124. Id. at 52-53.

125. Cf. Brief for the State of New York and Twenty-Six other States as Amici Curiae, in "Miranda Cases," pp. 23, 35-38; Brief for United States, p. 45, Westover v. United States, 384 U.S. 436 (1966). 
degree." If the legislative branch determined to forbid interrogation by the police and to exclude extrajudicial confessions thus obtained from evidence, it might meet the demands of law enforcement by providing a substitute such as an immediate examination by the prosecuting attorney in the presence of the counsel for the accused, or perhaps some system of quasi-judicial examination accompanied by a limitation, by constitutional amendment where necessary, of the privilege against self-incrimination. ${ }^{126}$

How an "immediate examination by the prosecuting attorney in the presence of the counsel for the accused" could possibly "meet the demands of law enforcement"-as law enforcement conceived those demands-is not made clear. Nor why a quasi-judicial examination of the accused might require a modification of the privilege although nonjudicial examination did not. For, and this is perhaps the most extraordinary feature of this extraordinary brief, the government agreed that the privilege against self-incrimination controlled the admissibility of confessions (as I read the brief, with some blinking, in state as well as federal cases), although, for one thing, it had to "sanitize" police interrogation in order to meet this standard:

$[T]$ he guarantees of the privilege against self-incrimination and of due process of law are limitations put upon the state in protection of the individual against invasions of "his indefeasible right" of personal security, personal liberty, and the privacies of life, where the right has not been forfeited by a conviction for crime. See Boyd v. United States, 116 U.S. 616, 630. But the constitutional prohibition is not laid upon only the most obnoxious practices. Even a restrained secret interrogation may gradually turn to mental or physical torture .... Therefore, the accused is given the privilege, which he may choose to exercise or not as he pleases, to check the danger at the outset by refusing to answer any incriminating questions; if he refuses, the state must not use "physical or moral compulsion to extort communications from him."

The Constitution grants this privilege specifically by the provision in the Fifth Amendment that no man "shall be compelled in any criminal case to be a witness against himself," and it grants the privilege impliedly in the due process clause of the Fifth and Fourteenth Amendments.

An accused person feels compulsion to speak, at the outset, in the hope of establishing his innocence and, at the end, when that is gone, in the weight of his conscience, or in the hope of obtaining Ieniency. But in such a case, the state cannot be said to have coerced (1943).

126. Brief for United States, pp. 55-56, Anderson v. United States, 318 U.S. 350 
the answers. The state has not invaded any right of personal security or privacy against the will of the accused, or exerted moral or physical compulsion to extort the communication. Such a confession, therefore, is admissible.

[A] confession made in answer to interrogation by the police may be admitted in evidence without infringement of any constitutional right, provided that the accused is left free to end the examination into his guilt or innocence by a refusal to answer, and provided that his will is respected and not subjugated to the will of his accusers. ${ }^{127}$

If there has ever been an alleged "coerced confession" case worth litigating where the defendant was given either the privilege against self-incrimination to exercise "as he pleases" or the freedom to "end the examination" by a simple refusal to answer, I am unaware of it. At any rate, not until Miranda did the Court strive to check "the danger [of secret interrogation] at the outset" by requiring that the suspect be fully and fairly advised that he has a "right of silence" which he may "choose to exercise . . . as he pleases." This, as I understand it, is what much of the shouting is about. Not until Miranda did the Court make plain that even though the suspect may have answered some questions or volunteered some statements he is "free to end the examination" by indicating that he does not wish to be interrogated further. Again, this, I take it, is what much of the shouting is about.

It is no mean feat to put beyond the reach of the privilege those proceedings in which a man is being "compelled"--in almost pristine form-to testify against himself. But it takes real dexterity to do what the government did in $M c N a b b$ and Anderson, i.e., purport to apply the privilege to a phase of the criminal process which had grown up more or less accidentally and extralegally, yet conclude that this application of the constitutional provision does not change things very much. In order to accomplish such an extraordinary feat, the Government not only had to tidy up the facts to suit the standard, but also had to loosen the standard to suit the facts. As the Government perceived the matter, the privilege against self-incrimination turned out to be little, if anything, more than the "voluntary" test masquerading under a different label. Whether the route taken in arriving at this result be viewed as augmenting the common law and due process standards a bit or as diluting the force of the privilege (at least as it had been construed in more 
formal settings) a good deal, all the tests, even the one based on "trustworthiness" wound up in a single ball of wax:

It is familiar and settled law that a "voluntary" confession should be admitted into evidence, and that a "coerced" confession should be excluded. Whatever the logic of the criticisms, this test is applicable whether the due process clauses of the Fifth and Fourteenth Amendments, the constitutional privilege against selfincrimination, or the law of evidence be invoked as ground for the objection.

The privilege is not to be "compelled" to give evidence against oneself. And in the leading cases setting aside convictions based upon confessions because due process was denied, the Court carefully pointed out that "the undisputed facts showed that compulsion was applied." Chambers $v$. Florida ... Coercion and compulsion exist in this sense when the accused is deprived "of his free choice, to admit, to deny, or to refuse to answer," when his will is broken so that he will make whatever statement his inquisitors may desire .... A confession obtained from a Chinese suffering physical pain who was held incommunicado and questioned for seven days and all of one night is obtained by compulsion. Wan $v$. United States, 266 U.S. 1. [Is this example supposed to illuminate the meaning of "compelled" to be a witness against oneself?]

Comparison of the constitutional requirement with the criterion of testimonial worth shows that they are essentially the same both in abstract statement and in practical application. Both are summarized in the words "voluntary" and "compulsion" .... In theory, it may be that a man is less ready to accuse himself falsely than he is to surrender his will to remain silent, but it is doubtful that so fine a line can be drawn in practice. The two aims, to admit true confessions and to abolish abuses, are overlapping; the ultimate test in each case is whether the confession is what the accused was willing to say or what the accusers wished him to tell them. ${ }^{128}$

As the government's approach in $M c N a b b$ and Anderson well illustrates, excluding the privilege from the interrogation room is not the only way to reconcile the proceedings inside with the fifth amendment. One may also let the privilege in, but "balance" it. "Outside" the interrogation room, unlike first amendment rights whose assertion "to bar governmental interrogation . . . always involves a balancing by the courts of the competing private and public interests at stake in the particular circumstances shown,"129 "a proper claim of the privilege against self-incrimination . . . af- 
ford[s] a witness the right to resist inquiry in all circumstances."130 "Outside," the most pressing demands of national security cannot override the privilege; "inside," evidently, routine law enforcement needs may, and often should, prevail. That, at least, is how I view the government's plea of a quarter-century ago to maintain the status quo, to stick with the old "voluntariness" test (alias the privilege against self-incrimination):

If all extra judicial confessions were excluded from evidence, there would be less aggression against these liberties because the incentive would be largely removed. On the other hand, it is essential that crime be detected and important that all data having testimonial worth be used to establish the guilt or innocence of the accused. Thus, there is a conflict between the demands of individual liberty and the public interest in efficient law enforcement. The test of voluntariness seems to us to resolve this conflict at the line marked by the Constitution. It should not, we submit, be modified by the courts to be more stringent. ${ }^{131}$

As late as 1966, the dissenters in Miranda seemed to agree. . . .

\section{The "Voluntariness" Test: "A Workable and Effective means of Dealing with Confessions in a Judicial Manner"}

Although Justice Clark would modify the old test, ${ }^{132}$ he looks back on it as one "which we are accustomed to administering and

130. Ibid.

131. Brief for United States, op. cit. supra note 126, at 38 .

A short time earlier, Sam Bass Warner, principal draftsman of the Uniform Arrest Act, who was said to be one of the few professors who had "accompanied the police on their tours of duty in order to learn and report the true facts," Wilson, Police Arrest Privileges in a Free Society: A Plea for Modernization, in POLICE POWER AND Individual FREedom 21, 26 (Sowle ed. 1962), had articulated "the conflict" and the need to strike "a proper balance" much more crisply:

The difficulties confronting a defendant who desires to reserve his story until trial are well-known. When he is arrested, the police will endeavor to make him "come across." Whether they will violate the Fifth Amendment by compelling him to be a witness against himself, depends upon what is meant by "compelling." If the term "compel" includes a two or three hour examination during which several police officers urge him to confess and do their best to confuse and entrap him into a confession, then the Fifth Amendment is violated in every city in the United States.

If in their effort to break down the suspect, our police stopped after giving him a severe grilling for a few hours, we might believe that the Fifth Amendment was being violated and regret that the liberty of the individual was not better respected, but we should have no serious ground for complaint. In fact, it may well be that a proper balance between the individual interest in freedom from compulsory self-incrimination and the social interest in the discovery of crime requires that suspects be subjected to such a cross-examination. The situation becomes serious only when the police go further and indulge in what is popularly known as the "third degree."

Warner, supra note 116, at 25. See also notes 141-43 infra and accompanying text.

132. See notes 4 and 11 supra. 
which we know from our cases are effective instruments in protecting persons in police custody." 133 For Justice Harlan, the preEscobedo-Miranda cases "show that there exists a workable and effective means of dealing with confessions in a judicial manner"134 and that "the court has developed an elaborate, sophisticated, and sensitive approach to admissibility," one "ever more familiar to the lower courts."135

Justice Clark's enthusiasm for the pre-Escobedo test was not always so abundant. Only five years earlier he had referred to "the elusive, measureless standard of psychological coercion heretofore developed in this Court by accretion on almost an ad hoc, case-bycase basis." 136 And long before that (in a search and seizure setting) he had scored the "uncertainty" and "unpredictability" generated by "a case by case approach to due process in which inchoate notions of propriety concerning local police conduct guide our decisions," maintaining that by such an approach "we do not shape the conduct of local police one whit; unpredictable reversals on dissimilar fact situations are not likely to curb the zeal of those police and prosecutors who may be intent on racking up a high percentage of successful prosecutions."137 As for Justice Harlan, in stressing that the late, lamented test gave "ample recognition to society's interest in suspect questioning as an instrument of law enforcement," 138 he succeeded, it seems to me, in violently shaking the aforementioned assurance by Justice Clark that the pre-EscobedoMiranda test was "an effective instrument in protecting persons in police custody":

Cases countenancing quite significant pressures can be cited without difficulty, and the lower courts may often have been yet more tolerant. ${ }^{139}$

133. 384 U.S. at 503.

134. Id. at 506.

135. Id. at 508 .

136. Reck v. Pate, 367 U.S. 433, 455 (1961) (dissenting opinion).

137. Irvine v. California, 347 U.S. 128, 138-39 (1954) (Clark, J., concurring).

138. 384 U.S. at 509.

139. Ibid., referring to the cases synopsized in Herman, The Supreme Court and Restrictions on Police Interrogation, 25 OHо ST. L.J. 449, 456 \& nn.36-39 (1964). See also Haynes v. Washington, 373 U.S. 503, 524 (1963) (Clark, J., joined by Harlan, Stewart and White, JJ., dissenting):

[Not] even the fact that one is "held incommunicado, is subjected to questioning by officers for long periods, and deprived of the advice of counsel," without a showing that he had "so lost his freedom of action" that the confession was not his own, requires a reversal under the Fourteenth Amendment. Lisenba v. California [314 U.S. 219, 240-41 (1941)]. Finally, the fact that police officers violated state statutes in their treatment of the petitioner does "not furnish an answer" to the question whether a confession was voluntarily made. Id. at 285; see Gallegos v. Nebraska, 342 U.S. 55 (1951). 
One not too distant example is Stroble v. California, 343 U.S. 181 [1952], in which the suspect was kicked and threatened after his arrest, questioned a little later for two hours, and isolated from a lawyer trying to see him; the resulting confession was held admissible. ${ }^{140}$

The Miranda majority contended that "the absurdity" of denying that a confession obtained under typical "interrogation room" circumstances "is compelled" is "aptly portrayed" by Professor Arthur Sutherland's hypothetical of a well-to-do testatrix who is "captured" by the would-be heirs who "put her in a carefully designed room, out of touch with everyone but themselves ... [and] keep her secluded there for hours while they make insistent demands, weary her with contradictions of her assertions that she wants to leave her money to [someone else], and finally induce her to execute the will in their favor." 141

Justice Harlan's retort was that the need of law enforcement "is, of course, what makes so misleading the Court's comparison of a probate judge readily setting aside as involuntary the will of an old lady badgered and beleagured by the new heirs." 142 However, after posing his hypothetical, Professor Sutherland had commented:

At once one will hear the response that the testatrix is not a criminal; that obtaining a surrender of rights from a criminal is different; that the interest of the state demands that criminals be not coddled. That is to say we are told that a man with his life at stake should be able to surrender an ancient constitutional right to remain silent, under compulsions which in a surrender of a little property would obviously make the transaction void.143

This is precisely what Justice Harlan seems to be telling us.

The view that the "voluntariness test" effectively protected suspects seems questionable, in large part because Justice Harlan's sanguine attitude about the "workability" of the "voluntariness" test and the test's growing familiarity to the lower courts seems unwarranted. His attitude hardly finds support in his own recognition that the Court "never pinned [the "voluntariness rubric"] . . . down

140. 384 U.S. at 509 n.5. As Justice Harlan recognizes elsewhere, see text at note 145 infra, in the evolution of the "totality of circumstances" test the use of physical violence in obtaining a confession emerged as a per se ground for inadmissibility, but "causation" questions remained. Stroble, sentenced to death for first degree murder, did not prevail in the Supreme Court because circumstances indicated that he had confessed "quite independently of any duress by the police." 343 U.S. at 191 (Clark, J.).

141. 384 U.S. at $457-58$ n.26, quoting from Sutherland, Crime and Confession, 79 HARV. L. REv. 21, 37 (1965).

142. 384 U.S. at 516 \& n.13. Compare note 131 supra.

143. Sutherland, supra note 141 , at 37. 
to a single meaning, but on the contrary infused it with a number of different values"144 or in his acknowledgment that "apart from direct physical coercion ... no single default or fixed combination of them guaranteed exclusion and synopses of the cases would serve little use because the overall gauge has been steadily changing, usually in the direction of restricting admissibility."145 Nor does the touted workability, effectiveness, sophistication and sensitivity of the old test find support in the Bator-Vorenberg article (which Justice Harlan quotes with approval):

In fact, the concept of involuntariness seems to be used by the courts as a shorthand to refer to practices which are repellent to civilized standards of decency or which, under the circumstances, are thought to apply a degree of pressure to an individual which unfairly impairs his capacity to make a rational choice. ${ }^{\mathbf{1 4 6}}$

Nor can the defenders of the old test gain much comfort from the paragraph (which the dissenting Justices do not quote) immediately preceding the one quoted above:

Judicial decisions speak in terms of the "voluntariness" of a confession, but the term itself provides little guidance. To the extent "voluntariness" has made a determination of the state of an individual's will the crucial question, it has not assisted analysis. Except where a person is unconscious or drugged or otherwise lacks capacity for conscious choice, all incriminating statements-even those made under brutal treatment are "voluntary" in the sense of representing a choice of alternatives. On the other hand, if "voluntariness" incorporates notions of "but-for" cause, the question should be whether the statement would have been made even absent inquiry or other official action. Under such a test, virtually no statement would be voluntary because very few people give incriminating statements in the absence of official action of some kind. ${ }^{147}$

144. 384 U.S. at 507.

145. Id, at 508 .

146. Bator \& Vorenberg, Arrest, Detention, Interrogation and the Right to Counsel, 66 Colum. L. Rev. 62, 73 (1966), quoted with approval, 384 U.S. at 507 n.4; cf. Kamisar, What Is An "Involuntary" Confession?, 17 RutGers L. Rev. 728, 745-46 (1963):

There is much talk in Culombe [v. Connecticut, 367 U.S. 568 (1961)] of "involuntariness" and the "suction process;" of "draining" the "capacity for freedom of choice"; of "overreaching," "overbearing" or "breaking" the "will." But are these words and phrases any more illuminating than say, the talk of yesteryear about "affected with a public interest," "subject to the exercise of the police power," or "devoted to the public use?" Is "involuntariness" or "coercion" or "breaking the will" (or its synonyms) little more than a fiction intended to vilify certain "effective" interrogation methods? Is "voluntariness" or "mental freedom" or "self-determination" (or its equivalents) little more than a fiction designed to beautify certain other interrogation techniques?

147. Bator \& Vorenberg, supra note 146 , at $72-73$. 
Justice Harlan did not pause to document his assertion that the pre-Escobedo approach to the admissibility of confessions-which was undergoing "a continuing re-evaluation on the facts of each case of how much pressure on the subject was permissible"148_was growing "ever more familiar to the lower courts." Similarly, although Professors Bator and Vorenberg talk about "the courts" using the voluntary-involuntary terminology as a "shorthand," they do not cite a single lower court case-only a host of United States Supreme Court cases and one secondary authority whose complaint, inter alia, is that by continuing to define the "voluntariness" required by due process in terms of the old threadbare generalities and empty abstractions (e.g., "made ... freely and voluntarily and without fear of punishment or hope of reward") and by failing to advise juries of specific types of police misconduct relevant to the issue, the state trial courts were permitting the term to continue to be used in its ordinary, everyday (and unhelpful) sense. ${ }^{148}$ Indeed, in Haynes $v$. Washington, 150 which marks the "end of the line" for the old test, the jury was instructed, in effect, to preclude from its consideration of the "voluntariness" issue that the accused was not reminded he was under arrest, was not cautioned he could remain silent, nor warned that his answers could be used against him, nor advised of his right to counsel. ${ }^{151}$ True, although not relied on as a separate ground of reversal, these instructions were regarded by the 5-4 Haynes majority as raising "a serious and substantial question whether a proper constitutional standard was applied by the jury." 152 There seems to be a significant difference, however, between forbidding a trial court from precluding consideration of these factors and requiring the court to instruct affirmatively that they must be taken into account.

The most ambitious attempt to bring order, coherence and clarity to the "involuntary" or "coerced" confession field, the most

148. 384 U.S. at 507. (Emphasis in the original.)

149. See Kamisar, supra note 146, at 752-58.

Actually, as Professors Bator and Vorenberg point out in the opening footnote, since their article is "an informal working paper, designed to be used as a basis for discussion," it "contains no documentation of any sort." However, the authors are the principal draftsmen of the American Law Institute's Model Code of Pre-Arraignment Procedure, and, understandably, the commentary to the proposed code, written at about the same time as the article, follows it closely. The passage quoted by Justice Harlan appears verbatim in the commentary, Model Code of Pre-Arraignment ProCEDURE 167 (Tent. Draft No. 1, 1966), and when I refer to Professors Bator and Vorenberg's documentation for this passage I mean that which is contained in the commentary to the code.

150. 373 U.S. 503 (1963).

151. Id. at 518 .

152. Ibid. 
arduous effort to develop "a set of principles [in terms of the old test] which cuuld be easily applied in any coerced-confession situation," 153 was the late Justice Frankfurter's sixty-seven page "treatise" 154 in Culombe $v$. Connecticut. ${ }^{155}$ What was the result of these Herculean labors? Justice Harlan, joined by Justices Clark and Whittaker, "agreed to what my Brother Frankfurter has written in delineation of the general principles governing police interrogation . . . and as to the factors which should guide federal judicial review of state action in this field"158_but reached the opposite result. ${ }^{157}$ Justice Douglas, joined by Justice Black, took a different route than did Justice Frankfurter, but reached the same result. ${ }^{158}$ The Chief Justice, in the course of joining the separate concurring opinion of Justice Brennan, would only say of the general principles enunciated by Justice Frankfurter: "On an abstract level, I find myself in agreement with some portions of the opinion and in disagreement with other portions." 159 Only one member of the Court, Justice Stewart, joined in Justice Frankfurter's dissertation.

Two years after Culombe and only a year before Escobedo, the Court split 5-4 in Haynes. ${ }^{160}$ Justice Clark, joined by Harlan, Stewart and White, JJ., regarded "the Court's reversal ... . [as] an abrupt departure from the rule laid down in the cases of this Court and an enlargement of the requirements heretofore visited upon state courts in confession cases." 161 For the majority's determination that the Haynes confession was "involuntary" the four dissenters could "find no support in any of the thirty-three cases decided on the question by this Court."162 Does this sound like the Supreme Court, let alone the lower courts, had grown "accustomed to administering" the "voluntariness" test?

For me, the strongest evidence of the ineffectiveness and unworkability of the old test was yet to come. It came one week after the Miranda case, when, having declined to give retroactive effect

153. So described by the Chief Justice in his concurring opinion, 367 U.S. at 636.

154. Again so described by the Chief Justice, 367 U.S. at 636. The Miranda dissenters were gracious enough not to elaborate on the Chief Justice's preference in Culombe for developing "the law on a case-by-case approach," declaring "legal principles only in the context of specific factual situations," and avoiding "expounding more than is necessary for the decision of a given case." Ibid.

155. 367 U.S. 568 (1961).

156. Id. at 642 (dissenting opinion).

157. Ibid.

158. Id. at 637-41.

159. $I d$. at 636.

160. 373 U.S. 503 (1963).

161. Id. at 521 .

162. Id. at 525 . 
to Escobedo and Miranda, ${ }^{163}$ the Court applied the old test (on collateral attack) in Davis $v$. North Carolina. ${ }^{164}$

As indicated earlier, ${ }^{165}$ in challenging the admissibility of his confessions, Elmer Davis, Jr., was more fortunate than most in his predicament. He could point to a specific notation on the arrest sheet: "Do not allow anyone to see Davis. Or allow him to use the telephone." 168 As Chief Judge Sobeloff pointed out, "rarely do police officials make a written declaration, as they did here, of a design to deny their prisoner's right to counsel and his other constitutional rights." 167 Davis could also point to the uncontested fact that no one other than the police had spoken to him during the sixteen days of detention and interrogation that preceded his confessions. The Supreme Court had "never sustained the use of a confession obtained after such a lengthy period of detention and interrogation as was involved in this case." 168 However, this did not suffice in the Superior and Supreme Courts of North Carolina in the year 1960. ${ }^{169}$ Nor did it impress the federal district court, which first denied him

163. Johnson v. New Jersey, 384 U.S. 719 (1966).

Johnson recalls Judge Qua's observation a decade ago: "Practical considerations may impinge heavily and divert the development of theory from its straight logical course. We all know this occurs from time to time in our own courts and sometimes to the great advantage of the law and the community. Similar forces operate in Washington." Qua, Griffin v. Illinois, 25 U. CHI. L. REv. 143, 147 (1957). Although "the advantages" to "the community" of declining to apply Escobedo and Miranda retroactively are considerable, I think Johnson was wrongly decided, for reasons suggested by a series of leading questions in Hall \& Kamisar, Modern Criminal ProceDURE 503 (2d ed. 1966). How can the Court say that "while Escobedo and Miranda provide important new safeguards against the use of unreliable statements at trial, the nonretroactivity of these decisions will not preclude persons whose trials have already been completed from invoking the same safeguards as part of an involuntariness claim"? 384 U.S. at 730. (Emphasis added.) If, as seems plain, Escobedo and Miranda indicate dissatisfaction with-and lack of confidence in-the actual operation of the old "voluntariness" and "totality of circumstances" tests, just as Gideon v. Wainwright, 372 U.S. 335 (1963) manifests dissatisfaction with and lack of confidence in the old Betts "prejudice" and "special circumstances" standards, how can it be sufficient that "our law on coerced confessions is available for persons whose trials have already been completed"? 384 U.S. at 730 .

I hasten to add, however, that here again, compare note 8 supra, the Court was faced with a "damned if it did and damned if it didn't" issue. If the Court had given the new confession rulings retroactive effect, I venture to say the roar of disapproval would have been deafening. Not only would many law enforcement officers have proclaimed "chaos" and "catastrophe," but not a few law professors would have chided the Court for "pretending the Constitution is now what it always was" and for "inhibiting judicial creativity."

164. 384 U.S. 737 (1966).

165. See notes 15-16 supra and accompanying text.

166. 384 U.S. at 744.

167. 339 F.2d 770, 780 (4th Cir. 1964). Judge Bell joined in Chief Judge Sobeloff's dissenting opinion.

168. 384 U.S. at 752 .

169. 253 N.C. 86,116 S.E.2d 365 (1960). 
an evidentiary hearing, ${ }^{170}$ and then, when reversed on this point, ${ }^{171}$ found his confessions to have been "voluntary."172 Nor, in the year 1964, was it quite enough for the United States Court of Appeals for the Fourth Circuit, which upheld denial of the writ by a 3-2 vote. ${ }^{173}$

The readiness with which the state and lower federal courts passing on the admissibility of Davis' confessions accepted dubious police claims, and the looseness with which they stated (or, more accurately, failed to state) "the facts," is hardly calculated to inspire confidence in the workability and effectiveness of the test-from the defendant's point of view, at any rate. In affirming Davis' conviction, a unanimous Supreme Court of North Carolina observed:

[T]he prisoner was advised he need not make a statement; that if he did it might be used against him.

The prisoner asked to see his sister, whom the officers searched for, after some difficulty found, and delivered the prisoner's message. She appeared at the jail and Captain McCall admitted her to a private conference with the prisoner. ${ }^{174}$

The prisoner's sister was admitted to a private conference with him, but, the state court neglected to point out, not until he had already confessed after having been interrogated "forty-five minutes or an hour or maybe a little more" each day for sixteen days. ${ }^{175}$ Similarly, the state court failed to note that there was no indication in the record that the prisoner was advised of his rights until the sixteenth day-after he had confessed orally but before he had signed the written confession. ${ }^{178}$

After holding a habeas corpus hearing, the federal district court had little difficulty concluding "from the totality of circumstances in this case that the confession was the product of a rational intellect and a free will." 177 How did it deal with the tell-tale notation on the police blotter directing that Davis be held incommunicado? It made no reference whatever to this incongruous item in its five page opinion, four of which are devoted to the "historical facts." Moreover, although the head of the detective division admitted

170. 196 F. Supp. 488 (E.D.N.C. 1961).

171. 310 F.2d 904 (4th Cir. 1962).

172. 221 F. Supp. 494 (E.D.N.C. 1963).

173. 339 F.2d 770 (4th Cir. 1964).

174. 253 N.C. $86,94,96,116$ S.E.2d $365,370,371$ (1960).

175. See 384 U.S. at $745-47 ; 339$ F.2d at 783 (dissenting opinion).

176. See $i d$. at $739 ; 339 \mathrm{~F} .2 \mathrm{~d}$ at 782 (dissenting opinion).

177. 221 F. Supp. 494, 499 (E.D.N.C. 1963). 
that Charlotte police sought and received permission from the warden of the state prison to keep Davis "temporarily" in their custody, primarily for the reason that they suspected him of the rapemurder to which he later confessed, ${ }^{178}$ they managed to convince the federal district court that, for the first twelve of the sixteen days he was their prisoner, they had refrained from asking Davis any questions about the murder, but rather confined their questions to thefts and unlawful entries committed by him after his escape. ${ }^{179}$

"The notation on the arrest record creates suspicions," conceded the 3-2 majority of the Fourth Circuit, "but such suspicions cannot overcome the positive evidence that the notation had no practical effect or influence upon what was done and that help rather than hindrance was offered to [Davis] in his one effort to contact someone outside the prison walls." ${ }^{180}$ This is the police version. The Fourth Circuit opinion pointed out elsewhere that Davis' sister had testified at the habeas corpus hearing that "she twice went to see her brother in the Charlotte City Jail, but each time was turned away."181 The district court, however, "did not believe her, finding, as the officers testified, that neither she nor anyone else was turned away . . . "182

What, if anything, one might ask, does the foregoing discussion prove? The United States Supreme Court reversed (Clark and Harlan, JJ., dissenting), did it not? Yes, indeed, but it should never be forgotten that in the thirty years since Brown $v$. Mississippi, ${ }^{183}$ the Supreme Court has taken an average of about one state confession case per year. ${ }^{184}$ How fared the many defendants all these years who, in the midst of the confusion and conflict so characteristic of "factual litigation" in this area, could not fall back on extraordinarily helpful "objective facts," as could Davis? How fared the many defendants whose cases did not receive the meticulous attention each Justice gives "death penalty" cases marked in red, ${ }^{185}$ as was Davis' case and two-thirds of the confession cases the Court has chosen to review these past thirty years?

178. See 384 U.S. at 743 n.3; 339 F.2d at 779,784 (dissenting opinion).

179. 221 F. Supp. at 496 . "Not humanly possible," asserted the dissenting judges in the Fourth Circuit, 339 F.2d at 784 .

180. 339 F.2d at 775 (Haynsworth, J.).

181. Ibid.

182. 221 F. Supp. at 496.

183. 297 U.S. 278 (1936).

184. Including Brown, the Court decided thirty-five state confession cases from 1936 through 1965. See National Legal Aid and Defender Association, Defender Newsletter, Vol. II, no. 5, Sept. 1965.

185. See Prettyman, JR., Death and the Supreme Court 305 (1961). 
Analyzing a recent Supreme Court Term, a careful student of that institution's work reported that the Court was asked to review over 2,000 cases, of which forty-two involved the death penalty. Although "all of the allegations in these capital cases were so serious that the Supreme Court might have felt compelled to decide each and every one of them" only one condemned man out of four received a hearing, and only one out of eight obtained a reversal. ${ }^{186}$ How many garden-variety criminal defendants who cried "coerced confession" but lost the "swearing contest" below were likely to survive the winnowing process above? As Justice Black put it in the Miranda oral arguments, "if you are going to determine it [the admissibility of the confession] each time on the circumstances . . . [if] this Court will take them one by one ... it is more than we are capable of doing." 187

Immediately prior to Escobedo and Miranda, could we afford to be proud of the progress we had made since the 1924 Ziang Sun Wan case? On that occasion two lower federal courts upheld a confession obtained from a seriously ill Chinese who had been held incommunicado for over a week, most of the time in a secluded hotel room where he was questioned "morning, afternoon and evening (and at least on one occasion after midnight)."188 (The Government met a much cooler reception in the Supreme Court than it had enjoyed in the lower courts when it depicted the case as one in which the defendant "had voluntarily acquiesced in going to the hotel; he had never complained of the presence of officers there with him ... he had been in a good humor all the time about the matter.") ${ }^{189}$

Had we made forty years worth of progress since the 1927 Doran case where, despite a powerful dissent by Judge Lehman, joined by Chief Judge Cardozo, what was probably the finest state court in the land affirmed a murder conviction based on a confession elicited from a man who had admittedly fainted during the "questioning," who had needed to be revived with whiskey and who admittedly had been "talked to" by an officer wearing a boxing glove on his hand ${ }^{190}$ (A majority of the New York Court of Appeals, per Crane, J., had speculated that "realization of the horrible deed which had

186. Id. at 297-98.

187. Unofficial Transcript of Oral Argument in Miranda and Companion Cases, p. 91 (oral argument of Mr. Earle for petitioner in Vignera v. New York), on file in University of Michigan Law Library.

188. 266 U.S. I, 11 (1924).

189. Brief for the United States, p. 43.

190. 246 N.Y. $409,422-23,159$ N.E. 379,384 (1927). 
been committed and that at last he had been discovered" might have caused the defendant to faint. ${ }^{191}$ As for the boxing glove, the majority conceded "this surely was a foolish thing for [the officer] to do, but it was to be considered by the jury with all the other testimony in determining the truth or falsity of Doran's statement about the use of violence." $)^{122}$

True, this was a long time ago, but the lower federal courts in Ziang Sun Wan and the state courts in Doran utilized a "voluntariness" test not much different from the one still being employed at least by the lower courts in the 1960 's. ${ }^{193}$ Could we confidently assert that confessions obtained on Wan and Doran type facts would never have passed muster in the lower courts in the ' 60 's?

A short week after they paid their respects to the late "voluntariness" test, Justices Clark and Harlan would have applied it to sustain Davis' confessions. The Court's reversal, they protested, "goes against the grain of our prior decisions."194 "[T]he sporadic interrogation of Davis," as they saw it, "can hardly be denominated as sustained or overbearing pressure. From the record it appears that he was simply questioned for about an hour each day [for sixteen days] by a couple of detectives. There was no protracted grilling. Nor did the police operate in relays." 195

"Disagreement," said Justice Harlan of the "voluntariness" test, "is usually confined to that borderland of close cases where it matters least." 196 After three decades and thirty-odd "coerced" confession cases which saw "the overall gauge . . . steadily changing, usually in the direction of restricting admissibility," 197 was Davis still a "close case"? If so, was the need to scrap the "voluntariness" test still a close question?

191. Id. at 422.

192. Id. at 423 .

193. Since the Wan jury was told that "in determining whether or not said confessions or admissions were voluntary" it "may take into consideration" that "the defendant was not warned that the confessions would or might be used against him or that he was not obliged to make any incriminating statement," that "the police repeatedly questioned him and importuned him to talk about the case" and other specific factors (Brief for the United States, p. 51), these instructions seem superior to those given in Haynes, some forty years later. See discussion in text at notes 149-51 supra. I am aware that Jackson v. Denno, 378 U.S. 368 (1964) required the trial court to actually determine the issue of "coercion" or "voluntariness" himself, at least in the first instance, but presumably how a judge instructs a jury on an issue is some evidence of how he himself would go about resolving that issue.

194. 384 U.S. at 753.

195. Id. at 754-55.

196. 384 U.S. at 509.

197. Id. at 508 . 